\title{
Hebbian Spike-Timing Dependent Plasticity at the Cerebellar Input Stage
}

\author{
DMartina Sgritta, ${ }^{1,3}$ Francesca Locatelli, ${ }^{1}$ Teresa Soda, ${ }^{1,4}$ Francesca Prestori, ${ }^{1}$ and Egidio Ugo D'Angelo ${ }^{1,2}$ \\ ${ }^{1}$ Department of Brain and Behavioral Sciences, University of Pavia, 27100 Pavia, Italy, ${ }^{2}$ Brain Connectivity Center, IRCCS C. Mondino, 27100 Pavia, Italy, \\ ${ }^{3}$ European Brain Research Institute Rita Levi Montalcini, 00143 Rome, Italy, and ${ }^{4}$ Museo Storico della Fisica e Centro Studi e Ricerche Enrico Fermi, 00184 \\ Rome, Italy
}

Spike-timing-dependent plasticity (STDP) is a form of long-term synaptic plasticity exploiting the time relationship between postsynaptic action potentials (APs) and EPSPs. Surprisingly enough, very little was known about STDP in the cerebellum, although it is thought to play a critical role for learning appropriate timing of actions. We speculated that low-frequency oscillations observed in the granular layer may provide a reference for repetitive EPSP/AP phase coupling. Here we show that EPSP-spike pairing at $6 \mathrm{~Hz}$ can optimally induce STDP at the mossy fiber-granule cell synapse in rats. Spike timing-dependent long-term potentiation and depression (st-LTP and st-LTD) were confined to a $\pm 25 \mathrm{~ms}$ time-window. Because EPSPs led APs in st-LTP while APs led EPSPs in st-LTD, STDP was Hebbian in nature. STDP occurred at $6-10 \mathrm{~Hz}$ but vanished $>50 \mathrm{~Hz}$ or $<1 \mathrm{~Hz}$ (where only LTP or LTD occurred). STDP disappeared with randomized EPSP/AP pairing or high intracellular $\mathrm{Ca}^{2+}$ buffering, and its sign was inverted by GABA-A receptor activation. Both st-LTP and st-LTD required NMDA receptors, but st-LTP also required reinforcing signals mediated by mGluRs and intracellular calcium stores. Importantly, st-LTP and st-LTD were significantly larger than LTP and LTD obtained by modulating the frequency and duration of mossy fiber bursts, probably because STDP expression involved postsynaptic in addition to presynaptic mechanisms. These results thus show that a Hebbian form of STDP occurs at the cerebellum input stage, providing the substrate for phase-dependent binding of mossy fiber spikes to repetitive theta-frequency cycles of granule cell activity.

Key words: cerebellum; granular layer; spike-timing-dependent plasticity

\section{Significance Statement}

Long-term synaptic plasticity is a fundamental property of the brain, causing persistent modifications of neuronal communication thought to provide the cellular basis of learning and memory. The cerebellum is critical for learning the appropriate timing of sensorimotor behaviors, but whether and how appropriate spike patterns could drive long-term synaptic plasticity remained unknown. Here, we show that this can actually occur through a form of spike-timing-dependent plasticity (STDP) at the cerebellar inputs stage. Pairing presynaptic and postsynaptic spikes at 6-10 Hz reliably induced STDP at the mossy fiber-granule cell synapse, with potentiation and depression symmetrically distributed within a $\pm 25 \mathrm{~ms}$ time window. Thus, STDP can bind plasticity to the mossy fiber burst phase with high temporal precision.

\section{Introduction}

The dualistic function of cerebellum as a "learning and a timing machine" has been early recognized (Eccles, 1967; Marr, 1969). The cerebellum can learn and store information about sensorimotor

\footnotetext{
Received June 29, 2016; revised Nov. 10, 2016; accepted Dec. 28, 2016.

Author contributions: E.U.D. designed research; M.S., F.L., and T.S. performed research; M.S. and F.P. analyzed data; F.P. and E.U.D. wrote the paper.

This work was supported by European Union Grant Human Brain Project HBP-29 604102 to E.U.D. and Fermi Grant 13(14) to E.U.D. and T.S.

The authors declare no competing financial interests.

Correspondence should be addressed to Dr. Egidio Ugo D'Angelo, University of Pavia, Department of Brain and Behavioral Sciences, via Forlanini 6, 27100 Pavia, Italy. E-mail: dangelo@unipv.it.

DOI:10.1523/JNEUROSCI.2079-16.2016

Copyright $\odot 2017$ the authors $\quad 0270-6474 / 17 / 372809-15 \$ 15.00 / 0$
}

contingencies and thereby control behavior with millisecond precision (Timmann et al., 1999; Osborne et al., 2007). Nonetheless, if and how timing of incoming signal control the induction of longterm synaptic plasticity remained to be demonstrated.

Fundamental elements of spike-timing and long-term synaptic plasticity have been recognized in the cerebellum; and the granular layer, located at the cerebellar input stage, has been proposed to exploit these mechanisms to regulate transmission and storage of complex spatiotemporal patterns (D'Angelo and De Zeeuw, 2009; Gao et al., 2012). On the one hand, different forms of long-term synaptic and nonsynaptic plasticity have been reported at the mossy fiber-granule cell synapse (D'Angelo, 2014), where LTP induction is favored by long high-frequency bursts and strong membrane depolarization, whereas LTD induction is 
favored by short low-frequency bursts and weak membrane depolarization (Sola et al., 2004; Gall et al., 2005; D'Errico et al., 2009). On the other hand, the mossy fiber-granule cell synapse is endowed with specific molecular mechanisms allowing high temporal precision (Silver et al., 1992; Cathala et al., 2005; Kanichay and Silver, 2008) and controlling the delay and persistence of spike emission (Nieus et al., 2006). Now the question is if and how spike-timing can drive synaptic plasticity. The key to understand this relationship is the observation that granule cells show coherent low-frequency oscillations in rats and monkeys in vivo (Pellerin and Lamarre, 1997; Hartmann and Bower, 1998; Courtemanche and Lamarre, 2005; D'Angelo et al., 2009) so that spike timing-dependent plasticity (STDP) may be able to detect the precise phase relationships between postsynaptic action potentials (APs) and EPSPs.

STDP is a form of long-term synaptic plasticity that exploits the temporal relationship of activity in presynaptic and postsynaptic neurons to regulate the switch between potentiation and depression (called here st-LTP and st-LTD) (Artola and Singer, 1993; Abbott and Nelson, 2000; Caporale and Dan, 2008; Markram et al., 2011). STDP typically requires repetitive EPSP/AP pairing at low frequency with a "time window" of $<100$ $\mathrm{ms}$ and shows a sharp transition between st-LTP and st-LTD; its magnitude is sensitive to the EPSP/AP interval (STDP degrades toward the edges of the time window) and depends on spike back-propagation and membrane depolarization (Markram et al., 1997; Bi and Poo, 1998; Zhang et al., 1998; Stuart and Häusser, 2001; Celikel et al., 2004; Sjöström and Häusser, 2006). STDP is defined Hebbian when potentiation occurs with EPSPs leading APs (st-LTP) and depression occurs with APs leading EPSPs (stLTD) (Hebb, 1949); vice versa, it is called anti-Hebbian (in both cases, spike back-propagation into the dendrites down to the synapses is needed, otherwise STDP in non-Hebbian). Various forms of STDP have been observed in several brain areas, including neocortex, striatum, hippocampus, and olfactory system (Debanne et al., 1998; Feldman, 2000; Sjöström et al., 2001; Froemke and Dan, 2002; Bender et al., 2006; Cassenaer and Laurent, 2007; Pawlak and Kerr, 2008). A form of non-Hebbian STDP has been observed at the parallel fiber Purkinje cell synapse of cerebellum (Safo and Regehr, 2008; Piochon et al., 2012), and anti-Hebbian STDP has been reported in the corresponding synaptic relay of cerebellum-like structures (electrosensory lobe of fishes and dorsal cochlear nucleus) (Bell et al., 1997; Tzounopoulos et al., 2004; Wu et al., 2015).

In this work, the induction of STDP over a theta-frequency cycle was investigated at the mossy fiber-granule cell synapse of cerebellum. This paradigm reliably led to Hebbian STDP that exploited induction and expression pathways that overlapped in part with those of LTP and LTD induced using duration/ frequency-modulated spike bursts (Gall et al., 2005; D'Errico et al., 2009; D'Angelo, 2014). Thus, this study suggests that STDP could have a relevant role in linking spike timing and learning at the input stage of the cerebellar circuit.

\section{Materials and Methods}

The experiments reported in this paper have been conducted on 17- to 22-day-old ( $\mathrm{P} 0=$ day of birth) Wistar rats of either sex according to protocols approved by the local ethical committee and by the European Commission (under Human Brain Project). The rats were anesthetized with halothane (Sigma) and killed by decapitation to remove the cerebellum for acute slice preparation according to a well-established technique (D'Angelo et al., 1995; Armano et al., 2000; Gall et al., 2005).

Slice preparation and solutions. The cerebellar vermis was isolated and fixed on the vibroslicer's stage (Leica VT12005) with cyano-acrylic glue.
Acute $220-\mu \mathrm{m}$-thick slices were cut in the parasagittal plane from in cold $\left(2^{\circ} \mathrm{C}-3^{\circ} \mathrm{C}\right)$ cutting-solution containing the following (in $\left.\mathrm{mM}\right): 130$ potassium gluconate, $15 \mathrm{KCl}, 0.2 \mathrm{EGTA}, 20$ HEPES, 10 glucose, pH 7.4 with $\mathrm{NaOH}$. Slices were incubated for at least $1 \mathrm{~h}$ at room temperature in oxygenated bicarbonate-buffered (Krebs') solution containing the following (in mM): $120 \mathrm{NaCl}, 2 \mathrm{KCl}, 1.2 \mathrm{MgSO}_{4}, 26 \mathrm{NaHCO}_{3}, 1.2 \mathrm{KH}_{2} \mathrm{PO}_{4}$, $2 \mathrm{CaCl}_{2}, 11$ glucose, $\mathrm{pH} 7.4$ (when equilibrated with $95 \% \mathrm{O}_{2}-5 \% \mathrm{CO}_{2}$ ), before being transferred to a recording chamber mounted on the stage of an upright microscope (Zeiss). The slices were perfused with oxygenated Krebs' solution and maintained at $32^{\circ} \mathrm{C}$ with a Peltier feedback device (TC-324B, Warner Instrument). For recordings, Krebs' solution was added with the $\mathrm{GABA}_{\mathrm{A}}$ receptor antagonist SR95531 (10 $\mu \mathrm{M}$; Tocris Bioscience). Local perfusion with Krebs' solution and $10 \mu \mathrm{M}$ SR95531 was commenced before seal formation and was maintained until the end of recording.

In a set of experiments, SR95531 (gabazine) was omitted from the extracellular solution. Patch pipettes were pulled from borosilicate glass capillaries (Hilgenberg) and, when filled with the intracellular solution, had a resistance of 7-9 $\mathrm{M} \Omega$ before seal formation. The whole-cell recording pipettes were filled with the following solution (in $\mathrm{mM}$ ): 126 potassium gluconate, $4 \mathrm{NaCl}, 5 \mathrm{HEPES}, 15$ glucose, $1 \mathrm{MgSO}_{4} \cdot 7 \mathrm{H}_{2} \mathrm{O}, 0.1$ BAPTA-free, 0.05 BAPTA-Ca ${ }^{2+}, 3 \mathrm{Mg}^{2+}$-ATP, $0.1 \mathrm{Na}^{+}$-GTP, pH 7.2 adjusted with $\mathrm{KOH}$. This solution maintained resting free $\left[\mathrm{Ca}^{2+}\right]$ at 100 $\mathrm{nM}$. In a different series of recordings, BAPTA was increased to $10 \mathrm{mM}$.

Electrophysiological recordings. Recordings were performed with Multiclamp 700B [ $-3 \mathrm{~dB}$; cutoff frequency (fc), $10 \mathrm{kHz}]$, sampled with Digidata 1550 interface, and analyzed off-line with pClamp10 software (Molecular Devices). Just after obtaining the cell-attached configuration, electrode capacitive transients were carefully cancelled to allow for electronic compensation of pipette charging during subsequent currentclamp recordings (D'Angelo et al., 1995, 1999). Mossy fiber stimulation was performed with a bipolar tungsten electrode (Clark Instruments) via a stimulus isolation unit. The stimulating electrode was placed over the central fiber bundle in the cerebellar lamina to stimulate the mossy fibers, and $200 \mu$ s step current pulses were applied at the frequency of $0.33 \mathrm{~Hz}$ (in specific experiments, paired-pulse stimulation at $20 \mathrm{~ms}$ interpulse was used). From comparison with previous data obtained in comparable conditions (Sola et al., 2004; D'Errico et al., 2009), between 1 and 2 mossy fibers were stimulated per granule cells. After evoking EPSCs at $-70 \mathrm{mV}$ at the test frequency for $10 \mathrm{~min}$ (control period), the recording was switched to current clamp. STDP protocols consisted of pairings of presynaptic and postsynaptic stimulations ( 60 times at 1,6 , or $10 \mathrm{~Hz}$ ) with a time interval $(\Delta t)$ that could either be fixed (phase-locked) or random. During random stimulation, EPSPs always occurred regularly at $6 \mathrm{~Hz}$, but the AP occurred casually between $25 \mathrm{~ms}$ and $-25 \mathrm{~ms}$. Therefore, the number of EPSPs and APs was the same as in phase-locked STDP experiments. In some experiments, we varied $\Delta t$ between -100 and $100 \mathrm{~ms}$ to fully explore the time window of plasticity induction. The time interval $\Delta t$ was defined as the time between the onset of the EPSP and the peak of the AP. Presynaptic activity corresponded to mossy fiber stimulations and postsynaptic activity to an AP evoked by a brief $(5 \mathrm{~ms})$ depolarizing current step $(40 \mathrm{pA})$ in the recorded granule cell. Long-term synaptic efficacy changes were measured after $20 \mathrm{~min}$. After delivering the STDP protocol, revoltage clamp at $-70 \mathrm{mV}$ was reestablished and stimulation was restarted at the test frequency.

The stability of whole-cell recordings can be influenced by modification of $R_{s}$. To ensure that $R_{s}$ remained stable during recordings, passive electrode-cell parameters were monitored throughout the experiments. The granule cell behaves like a lumped electrotonic compartment and can therefore be treated as a simple resistive-capacitive system, from which relevant parameters can be extracted by analyzing passive current relaxations induced by $10 \mathrm{mV}$ hyperpolarizing steps from a holding potential of $-70 \mathrm{mV}$ applied $10 \mathrm{~ms}$ before each mossy fiber stimulus (D'Angelo et al., 1995, 1999; Silver et al., 1996). The voltage clamp time constant, $\tau_{\mathrm{vc}}$, was estimated from biexponential fitting to current transients elicited by voltage steps. The $3 \mathrm{~dB}$ cutoff frequency of the electrodecell system was calculated as fvc $=\left(2 \pi \times \tau_{\mathrm{vc}}\right)^{-1}=2.1 \pm 0.1 \mathrm{kHz}(n=$ $120)$. Membrane capacitance $C_{\mathrm{m}}=3.2 \pm 0.1 \mathrm{pF}(n=120)$ was measured from the capacitive charge (the area underlying current transient), mem- 
brane resistance $\mathrm{R}_{\mathrm{m}}=1.6 \pm 0.1 \mathrm{G} \Omega(n=120)$ was obtained from the steady-state current flow, also yielding series resistance $\mathrm{R}_{\mathrm{s}}=\tau_{\mathrm{vc}} / \mathrm{C}_{\mathrm{m}}=$ $30.3 \pm 1.4 \mathrm{M} \Omega(n=120)$. In the cells used in this paper, these values did not significantly change after $30 \mathrm{~min}$ attesting recording stability. Otherwise, variation of series resistance $\left(\mathrm{R}_{\mathrm{s}}\right)>20 \%$ led to the rejection of the experiment.

Postsynaptic currents analysis and data processing. All EPSCs were digitally filtered at $1.5 \mathrm{kHz}$ and analyzed off-line. EPSC amplitude was measured as the difference between EPSC peak and the current level just before stimulation. The paired-pulse ratio (PPR) between the first and second $\mathrm{EPSC}$ in a sequence was $\mathrm{PPR}=\mathrm{EPSC}_{2} / \mathrm{EPSC}_{1}$. In specific experiments, the acquisition program automatically alternated EPSC with background activity recordings ( 1 and $9 \mathrm{~s}$, respectively), from which miniature EPSCs (mEPSCs) were detected. mEPSC analysis was performed automatically with Clampfit software, setting a proper threshold for event detection. A further visual inspection of detected signals allowed us to reject noisy artifacts. A $10 \mathrm{~min}$ period was used to evaluate mean mEPSC amplitude and coefficient of variation $(\mathrm{CV})$.

Data are mean $\pm \mathrm{SE}$, statistical comparisons are done using unpaired Student's $t$ test and differences are considered statistically significant at $p<0.05$.

Analysis of neurotransmission. In voltage-clamp recordings at $-70 \mathrm{mV}$, the fast component of mossy fiber-granule cell EPSCs is generated almost exclusively by activation of AMPA receptors (Silver et al., 1996; D'Angelo et al., 1999). In addition to the fast component (direct response; time to peak $<1.5 \mathrm{~ms}$ ), the EPSCs included a minor slow component (indirect response) due to neurotransmitter spillover (Nielsen et al., 2004; Sola et al., 2004). Neurotransmission failures usually showed only the indirect component. A minority of failures $(<2 \%)$ without the slow component were considered stimulation failures and were discarded from analysis. The error introduced in amplitude measurement by the failures, which have non- 0 amplitude due to the indirect response, was eliminated by setting the amplitude of the indirect responses to 0 (Sola et al., 2004). To investigate the expression mechanism of STDP (Sola et al., 2004; D'Errico et al., 2009; Mapelli et al., 2009), a simplified version of quantal analysis was performed by measuring the mean and SD of EPSC amplitude. All measurements were performed over $N=100$ contiguous EPSCs minimizing errors introduced by small samples (data not shown). EPSC changes, which do not strictly require that single synaptic connections are isolated, were obtained from mean $(\mathrm{M})$ and SD (S): the $\mathrm{CV}=\mathrm{S} / \mathrm{M}$ (Eq. 1) and the $\mathrm{PPR}=\mathrm{M}_{2} / \mathrm{M}_{1}$ (Eq. 2). In general, one should expect that both CV and PPR will increase (decrease) with a presynaptic LTD (LTP) expression, but would not change with a postsynaptic LTD (LTP) expression. The comparison between mean and CV obtained before (State A) and after (State B) the induction of STDP could be performed in the plot $\left(\mathrm{CV}_{\mathrm{B}} / \mathrm{CV}_{\mathrm{A}}\right)^{-2}<=>\left(\mathrm{M}_{\mathrm{B}} / \mathrm{M}_{\mathrm{A}}\right)$ (Eq. 3). The inequality leads to a topological representation of neurotransmission changes (see Fig. 8) and has been extensively used to interpret the plasticity mechanism (Bekkers and Stevens, 1990; Malinow and Tsien, 1990; Sola et al., 2004; D'Errico et al., 2009). Equation 3 has the following properties. For a mean increase: (1) when $\left(\mathrm{CV}_{\mathrm{B}} / \mathrm{CV}_{\mathrm{A}}\right)^{-2}>\left(\mathrm{M}_{\mathrm{B}} / \mathrm{M}_{\mathrm{A}}\right)$, both $n$ and $p$ can increase; (2) when $\left(\mathrm{CV}_{\mathrm{B}} / \mathrm{CV}_{\mathrm{A}}\right)^{-2}=\left(\mathrm{M}_{\mathrm{B}} / \mathrm{M}_{\mathrm{A}}\right)$, only $n$ can increase; and (3) when $\left(\mathrm{CV}_{\mathrm{B}} / \mathrm{CV}_{\mathrm{A}}\right)^{-2}<\left(\mathrm{M}_{\mathrm{B}} / \mathrm{M}_{\mathrm{A}}\right)$, neither $n$ nor $p$ can increase implying an increase in $q$. A pure increase in $q$ will lie on the axis $\left(\mathrm{CV}_{\mathrm{B}} / \mathrm{CV}_{\mathrm{A}}\right)^{-2}=1$.

For a mean decrease, complementary parameter changes are predicted. A confident interpretation of the plot can be achieved only providing independent estimates of $q$ and $\mathrm{cv}_{\mathrm{q}}$ because simultaneous changes of the parameters cannot be excluded by inspection (von Kitzing et al., 1994).

Calcium imaging. Calcium imaging was performed as reported previously in this same preparation (Gall et al., 2005; D'Errico et al., 2009), by using Oregon green BAPTA-1 (OG1, Invitrogen). Briefly, the intracellular solution was added with $0.2 \mathrm{~mm}$ OG1 in substitution to the BAPTA/ $\mathrm{Ca}^{2+}$ buffer. Granule cells were identified with a $\times 63,0.9$ NA waterimmersion objective (Olympus). Digital fluorescence images were obtained using an excitation light source from TILL Photonics controlled through Axon Imaging Workbench AIW5.2 (INDEC Systems). Images were acquired with a $50 \mathrm{~ms}$ exposure/image at video rate. Acquisition (frame rate $=2 \mathrm{~Hz}$ ) started after allowing $>2 \mathrm{~min}$ for dye loading in the neuron. After this time, the resting fluorescence $\left(\mathrm{F}_{0}\right)$ varied by $<5 \%$ in each analyzed cell region for the entire recording time, and the background fluorescence $\left(\mathrm{B}_{0}\right)$ was also stationary. Each protocol was preceded by $2 \mathrm{~s}$ of baseline, during which no stimulus was given, to allow subsequent $\mathrm{F}_{0}$ (basal $\left[\mathrm{Ca}^{2+}\right]_{\mathrm{i}}$ ) evaluation. $\left[\mathrm{Ca}^{2+}\right]_{\mathrm{i}}$ changes were first elicited during voltage-clamp recordings by depolarizing granule cells from -70 to $0 \mathrm{mV}$ for $400 \mathrm{~ms}$. This depolarization induced $\left[\mathrm{Ca}^{2+}\right]_{\mathrm{i}}$ changes in the dendrites, more evident at the level of terminal digits (Gall et al., 2005): $\left[\left(\Delta \mathrm{F} / \mathrm{F}_{0}\right)_{\max }=0.18 \pm 0.025 ; n=6\right]$. The $\left[\mathrm{Ca}^{2+}\right]_{\mathrm{i}}$ increase at the somatic level was very low $\left[\left(\Delta \mathrm{F} / \mathrm{F}_{0}\right)_{\max }=0.035 \pm 0.02, n=6\right]$. All stimulation protocols were separated by a minimum of $60 \mathrm{~s}$ to allow $\left[\mathrm{Ca}^{2+}\right]_{\mathrm{i}}$ to return to basal level. Cell damage was identified by the following signs: the failure of $200 \mathrm{~ms}$ depolarization at $0 \mathrm{mV}$ in voltage clamp to elicit a fluorescence transient or the sudden inability of fluorescence levels to recover to baseline after stimulation. We never observed bleaching of OG1 basal fluorescence during stimulations.

Stimulus-induced fluorescence changes were analyzed off-line in the regions of interest (ROIs). For each experiment, regions were drawn by eye defining the ROIs in the first image of a sequence, thus giving a set of two-dimensional arrays of pixels. In addition, background fluorescence was evaluated by defining a background area of similar size close to the cell. For each ROI, a measurement of the relative change in fluorescence during cell stimulation, $\Delta \mathrm{F} / \mathrm{F}_{0}$ ( $\mathrm{F}_{0}$ is the mean resting fluorescence), was obtained as follows: for each consecutive image in the sequence, the fluorescence intensity $\mathrm{f}_{(\mathrm{n})}$ was evaluated in the ROI. Background fluorescence was measured simultaneously in the background area, $\mathrm{B}_{(\mathrm{n})}$. Care was taken to check that background fluorescence was stationary. The background-subtracted fluorescence $F_{(n)}=f_{(n)}-B_{(n)}$ was then used to evaluate $\Delta \mathrm{F} / \mathrm{F}_{0(\mathrm{n})}=\left(\mathrm{F}_{(\mathrm{n})}-\mathrm{F}_{0}\right) / \mathrm{F}_{0}$, where $\mathrm{F}_{0}$ is the average backgroundsubtracted resting fluorescence over four consecutive images before applying the stimulus. This background subtraction procedure was used to account for slice auto-fluorescence and/or fluorescence arising from outflow of dye from the pipette before seal formation. As well as in our previous work (Gall et al., 2005; D’Errico et al., 2009), $\left[\mathrm{Ca}^{2+}\right]_{\mathrm{i}}$ was measured in the granule cell dendritic ending showing the most prominent fluorescence change, to exclude nonsynaptically activated dendrites, in which voltage-dependent calcium channels open due to electrotonic diffusion of depolarization.

Chemicals. The following chemicals were used at the indicated concentrations: D-APV (50 $\mu \mathrm{M}$; Tocris Bioscience), SR 95531 hydrobromide (gabazine $10 \mu \mathrm{M}$; Tocris Bioscience), and 7-chlorokynurenic acid sodium salt (50 $\mu \mathrm{m}$; Tocris Bioscience) were dissolved in the extracellular solution. (RS)-1-aminoindan-1,5-dicarboxylic acid (AIDA $15 \mu \mathrm{m}$; Tocris Bioscience) was perfused locally through a multibarrel pipette; and ruthenium red (10 $\mu \mathrm{M}$; Tocris Bioscience) and $1 \mathrm{mg} / \mathrm{ml}$ heparin (Tocris Bioscience).

\section{Results}

Whole-cell patch-clamp recordings were performed from granule cells in acute cerebellar slices of juvenile rats (P17-P22) using stimulation protocols designed to determine the presence of STDP. The average control EPSC size in the whole experimental dataset was $-41.5 \pm 2.7 \mathrm{pA}(n=112)$. After monitoring baseline EPSCs at low-frequency for $10 \mathrm{~min}$, the recording system was switched to current-clamp for STDP induction, then the EPSCs were monitored again for at least $30 \mathrm{~min}$. During induction, mossy fiber stimulation elicited subthreshold EPSPs, which were paired with a single postsynaptic AP generated by a $1 \mathrm{~ms}$ somatic current pulse (Fig. 1A). EPSP-AP pairing was repeated 60 times at $6 \mathrm{~Hz}$ using different EPSP-AP phases in different recordings (for similar protocols, see Bell et al., 1997; Feldman, 2000; Froemke and Dan, 2002; Froemke et al., 2005; Fung et al., 2016).

\section{Phase-locked pairing determines STDP}

When EPSP-AP pairing was performed maintaining the same EPSP-AP phase relationship over the 60 repetitions (phase- 
A
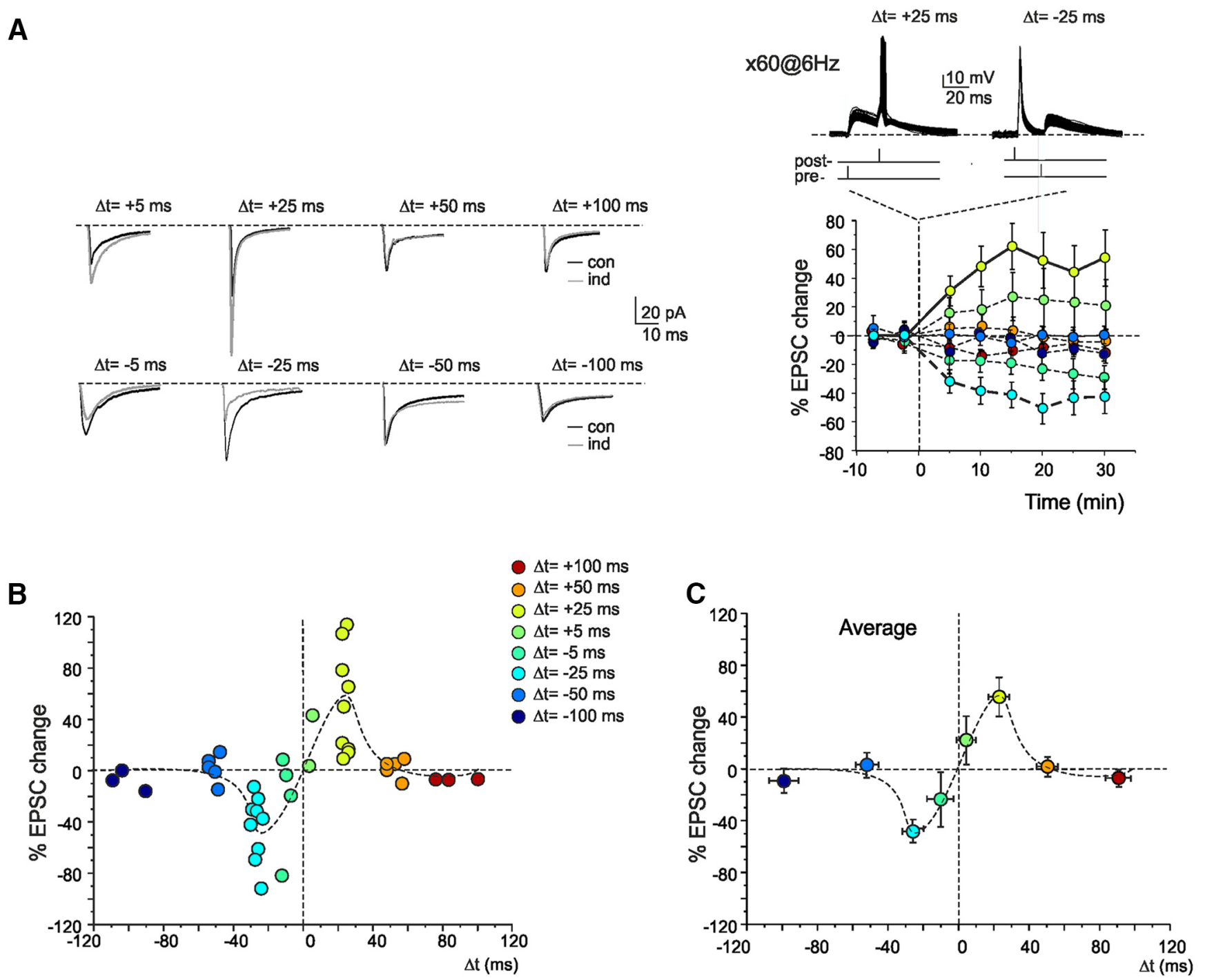

Figure 1. Spike timing-dependent induction of long-term synaptic plasticity in cerebellar granule cells. A, Left, EPSC traces (average of 100 individual sweeps) represent the changes observed following induction in different experiments. An EPSP evoked by extracellular stimulation (pre-) was paired with a spike elicited by current injection into the postsynaptic cell (post-). The spike followed or preceded the onset of the EPSP by $\Delta t= \pm 5, \pm 25, \pm 50$, and $\pm 100 \mathrm{~ms}$. Pairings was repeated 60 times at at $6 \mathrm{~Hz}$. Right, Plot represents the time course of EPSC amplitude changes for different $\Delta t$. For each series, data are expressed as percentage changes in EPSC peak amplitude compared with control (con) before induction (ind). Dashed line indicates the induction time. Each point indicates the average of 50 contiguous EPSC amplitudes. Top, Sample traces have been taken during STDP induction protocol. Data in the plot are mean \pm SEM. $\boldsymbol{B}$, Summary of the change in the EPSC amplitude for different $\Delta t$. The STDP timing curve shows EPSC amplitude changes in individual recordings 20 min after induction (each point is the average of 100 EPSC amplitude measurements). $\boldsymbol{C}$, Average EPSC amplitude changes in the same experiments as shown in $\boldsymbol{B}$. Data are mean \pm SEM. Note the striking transition from maximal LTP to maximal LTD over the narrow time window $\sim 0 \mathrm{~ms}$.

locking), the sign and degree of EPSC changes depended on the time interval $(\Delta t)$ between the onset of the EPSP and the peak of the AP (Fig. 1). When the AP followed the EPSP, EPSP-AP pairing with $0<\Delta t<25 \mathrm{~ms}$ induced long-term potentiation of EPSC amplitude (st-LTP: $47.4 \pm 11.7 \%, n=11, p<0.05$ ), whereas EPSP-AP pairing with $50<\Delta t<+100 \mathrm{~ms}$ did not induce any significant changes $(-1.5 \pm 2.5 \%, n=8, p=0.7)$. When the AP preceded the EPSP, EPSP-AP pairing with $0<\Delta t<-25 \mathrm{~ms}$ induced long-term depression of EPSC amplitude (st-LTD: $-37.7 \pm 8.5 \%, n=13, p<0.005$ ), whereas EPSP-AP pairing with $-50<\Delta t<-100 \mathrm{~ms}$ did not induce any significant changes $(-1.9 \pm 4.4 \%, n=8, p=0.4)$. In all cases, st-LTP and st-LTD lasted almost unaltered for the entire duration of recordings attesting their long-term nature (Fig. $1 A$ ). The STDP phaseplot showed an almost symmetric shape $\sim 0$ (Fig. $1 B$ ). Unless indicated otherwise, the data reported below refer to st-LTP at
$\Delta t=25 \mathrm{~ms}$ and st-LTD at $\Delta t=-25 \mathrm{~ms}$ (i.e., where the STDP changes were the largest).

To verify the STDP requirement for a phased-locked EPSP-AP pairing, in a series of recordings, the time between the EPSP onset and the AP peak was varied randomly during the theta cycle (Fig. 2A). After random EPSP-AP pairing, EPSC amplitudes were not significantly changed $(-1.4 \pm 1.9 \%, n=5 ; p=$ 0.8 ), showing that STDP induction was critically dependent on the maintenance of a precise EPSP-AP phase relationship over the stimulation cycles.

Furthermore, because the efficiency of pairing might be affected by the postsynaptic membrane voltage and hence by the activation state of postsynaptic receptors and ionic channels (Stuart and Häusser, 2001), we have considered whether EPSP amplitude could influence STDP. Indeed, there was no significant correlation between EPSP amplitude during induc- 
A

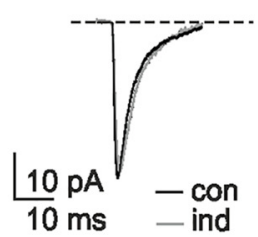

$B_{1}$

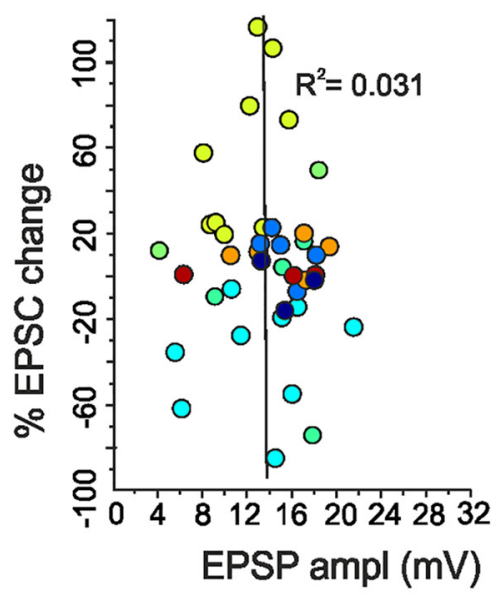

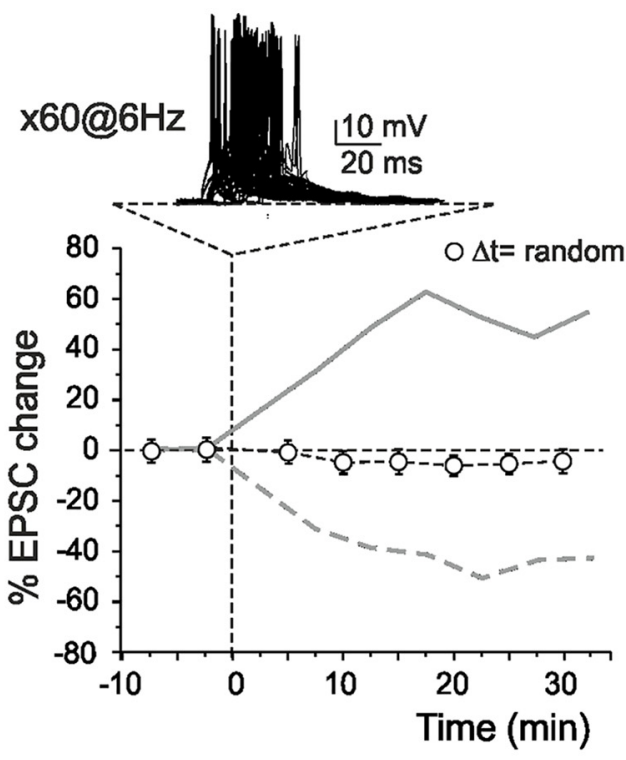

$B_{2} \quad$ Average

$\Delta t=+100 \mathrm{~ms}$

$\Delta t=+50 \mathrm{~ms}$

$\Delta \mathrm{t}=+25 \mathrm{~ms}$

$\Delta \mathrm{t}=+5 \mathrm{~ms}$

$\Delta t=-5 \mathrm{~ms}$

$\Delta \mathrm{t}=-25 \mathrm{~ms}$

$\Delta t=-50 \mathrm{~ms}$

$\Delta t=-100 \mathrm{~ms}$

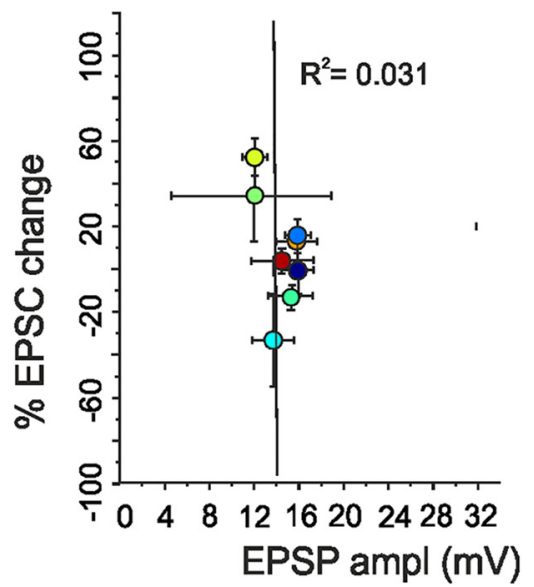

Figure 2. STDP requirement for a phased-locked EPSP-AP pairing. A, Left, Sample traces of EPSCs in control (con) and 20 min after STDP induction (ind) in a single cell (average of 100 sweeps) after random EPSP-AP pairing. Right, The time course shows average changes in EPSC amplitude after induction with random pairing. Gray lines replotted from Figure $1 A$ indicate STDP at $6 \mathrm{~Hz}$ with phased-locked pairing for comparison. Dashed line indicates the induction time. Each point indicates the average of 50 contiguous EPSC amplitude. Top, Sample traces have been taken during randomly STDP induction protocol. Data in the plot are mean \pm SEM. $\boldsymbol{B}_{1}$, Plot represents nonsignificant correlation between EPSP amplitude during induction and EPSC changes at different $\Delta t$ (linear regression; $R^{2}=0.03, n=40 ; p(F)=0.85$ ). $\boldsymbol{B}_{2}$, Average EPSC amplitude changes in the same experiments as shown in $\boldsymbol{B}_{1}$. Data are mean \pm SEM.

tion and EPSC changes at different $\Delta t$ (linear regression; $R^{2}=$ $0.03, n=40 ; p(F)=0.85$ ) (Fig. 2B). Thus, the intrinsic EPSP amplitude variability among cells did not influence STDP remarkably.

\section{STDP dependence on the input frequency}

A specific question about STDP induction concerns the eligible frequency window. We therefore repeated EPSP/AP pairing at 1 $\mathrm{Hz}$ and $10 \mathrm{~Hz}$ using $\Delta t= \pm 25 \mathrm{~ms}$ (i.e., where $6 \mathrm{~Hz}$ STDP is maximal) for 60 repetitions (to maintain their number constant at different frequencies). Figure 3 shows the time course of EPSC changes with $1 \mathrm{~Hz}$ and $10 \mathrm{~Hz}$ pairing. With $1 \mathrm{~Hz}$ pairing, STDP disappeared leaving only LTD both at positive EPSP/AP pairing $(\Delta t=25 \mathrm{~ms},-33.5 \pm 12.1 \%, n=5 ; p<0.05)$ and at negative
EPSP/AP pairing $(\Delta t=-25 \mathrm{~ms},-30.9 \pm 8.0 \%, n=5 ; p<$ 0.005). Conversely, with $10 \mathrm{~Hz}$ pairing, STDP was still present showing st-LTP at positive EPSP/AP pairing $(\Delta t=25 \mathrm{~ms}, 23.9 \pm$ $5.4 \%, n=4 ; p<0.05)$ and st-LTD at negative EPSP/AP pairing $(\Delta t=-25 \mathrm{~ms},-18.0 \pm 3.1 \%, n=5 ; p<0.05)$. It should be noted that STDP induction at $20 \mathrm{~Hz}$ was not tested because in that case pairing with $\Delta t=25 \mathrm{~ms}$ or $\Delta t=-25 \mathrm{~ms}$ would be equivalent (aliasing frequency) and the experiment would coincide with that already reported by D'Errico et al. (2009), that actually showed net LTP. A summary graph (Fig. 3C) shows stLTP and st-LTD at different frequencies along with the EPSC changes caused by frequency-dependent long-term synaptic plasticity reported previously for comparison (D'Errico et al., 2009). 
A
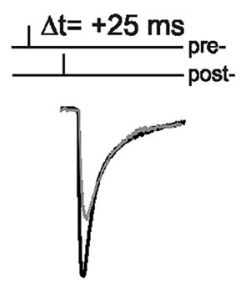

$\frac{10}{10} \mathrm{pA}$

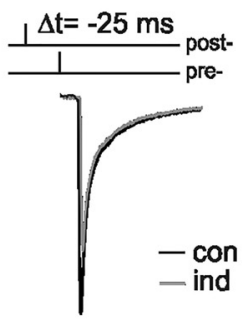

B

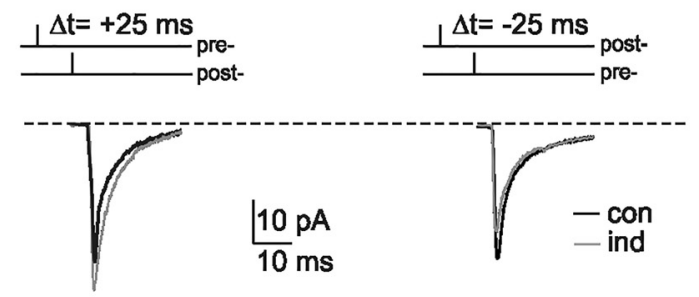

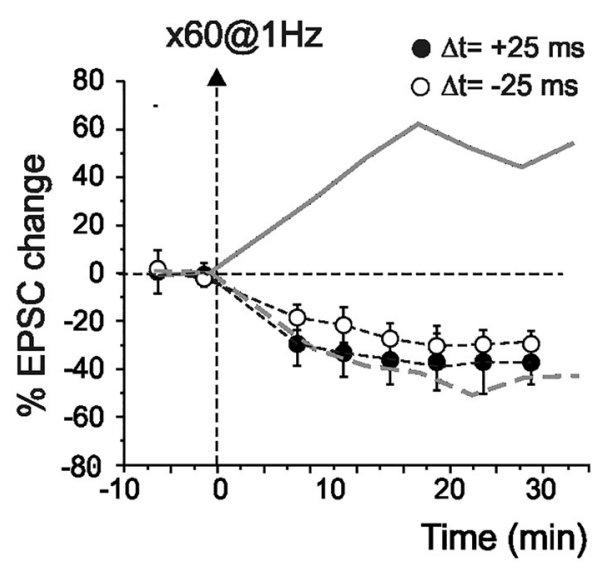

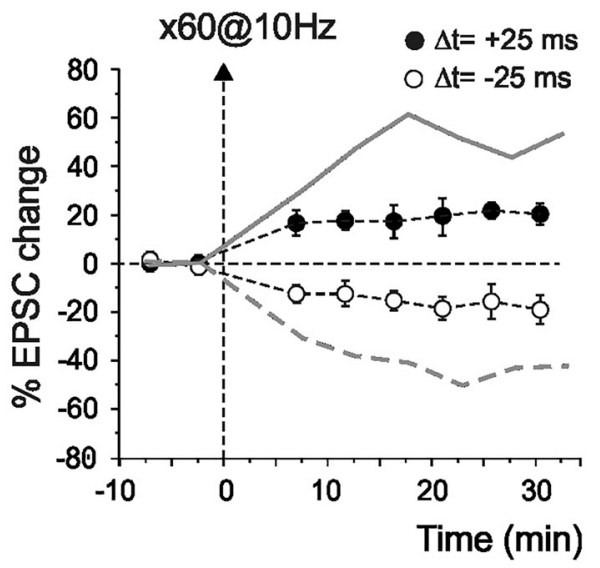

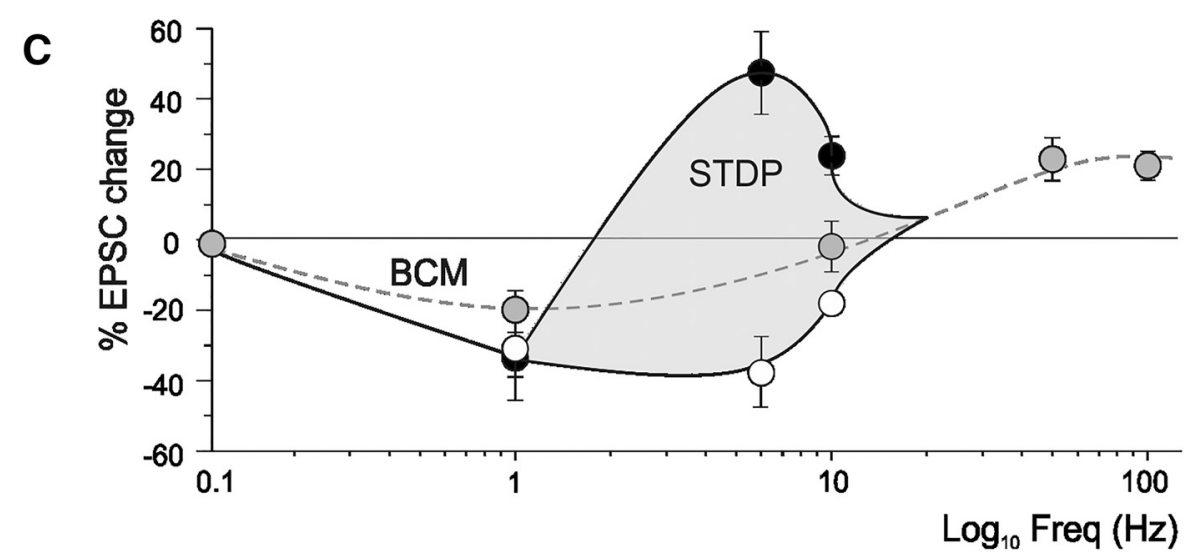

Figure 3. STDP dependence on the input frequency. $A$, Left, Sample traces of EPSCs in control (con) and 20 min after STDP induction (ind) in a single cell (average of 100 sweeps) after EPSP-AP pairing at $1 \mathrm{~Hz}$. Right, The time course shows average changes in EPSC amplitude after STDP induction. Gray lines replotted from Figure $1 A$ indicate STDP at $6 \mathrm{~Hz}$ with phased-locked pairing for comparison. Dashed line indicates the induction time. Each point indicates the average of 50 contiguous EPSC amplitude. Data in the plot are mean \pm SEM. B, Left, Sample traces of EPSCs in control (con) and 20 min after STDP induction (ind) in a single cell (average of 100 sweeps) after EPSP-AP pairing at $10 \mathrm{~Hz}$. Right, The time course shows average changes in EPSC amplitude after STDP induction. Gray lines replotted from Figure $1 A$ indicate STDP at $6 \mathrm{~Hz}$ with phased-locked pairing for comparison. Dashed line indicates the induction time. Each point indicates the average of 50 contiguous EPSC amplitude. Data in the plot are mean \pm SEM. C, The STDP changes obtained following AP-EPSP pairing at 1, 6, and $10 \mathrm{~Hz}$ are compared with those obtained from D'Errico et al. (2009). White circles represent st-LTD at $\Delta t=-25 \mathrm{~ms}$. Black circles represent st-LTP at $\Delta t=25 \mathrm{~ms}$. Gray circle represents $\Delta t=0 \mathrm{~ms}$. Data in the plot are mean $\pm \mathrm{SEM}$.

STDP dependence on postsynaptic $\mathrm{Ca}^{2+}$ changes and GABA-A receptors

In a different series of recordings, to investigate whether STDP depended on postsynaptic $\mathrm{Ca}^{2+}$ concentration $\left(\left[\mathrm{Ca}^{2+}\right]_{\mathrm{i}}\right)$ changes, the pipette intracellular solution was supplemented with the calcium buffer, $10 \mathrm{~mm}$ BAPTA. Figure $4 A$ shows the time course of EPSC changes. The high concentration of BAPTA prevented both st-LTP $(-5.3 \pm 5.7 \%, n=4 ; p=0.4)$ and st-LTD $(3.7 \pm 10.1 \%, n=4 ; p=0.6)$. These results indicate, therefore, that mossy fiber-granule cell STDP has postsynaptic calcium- 

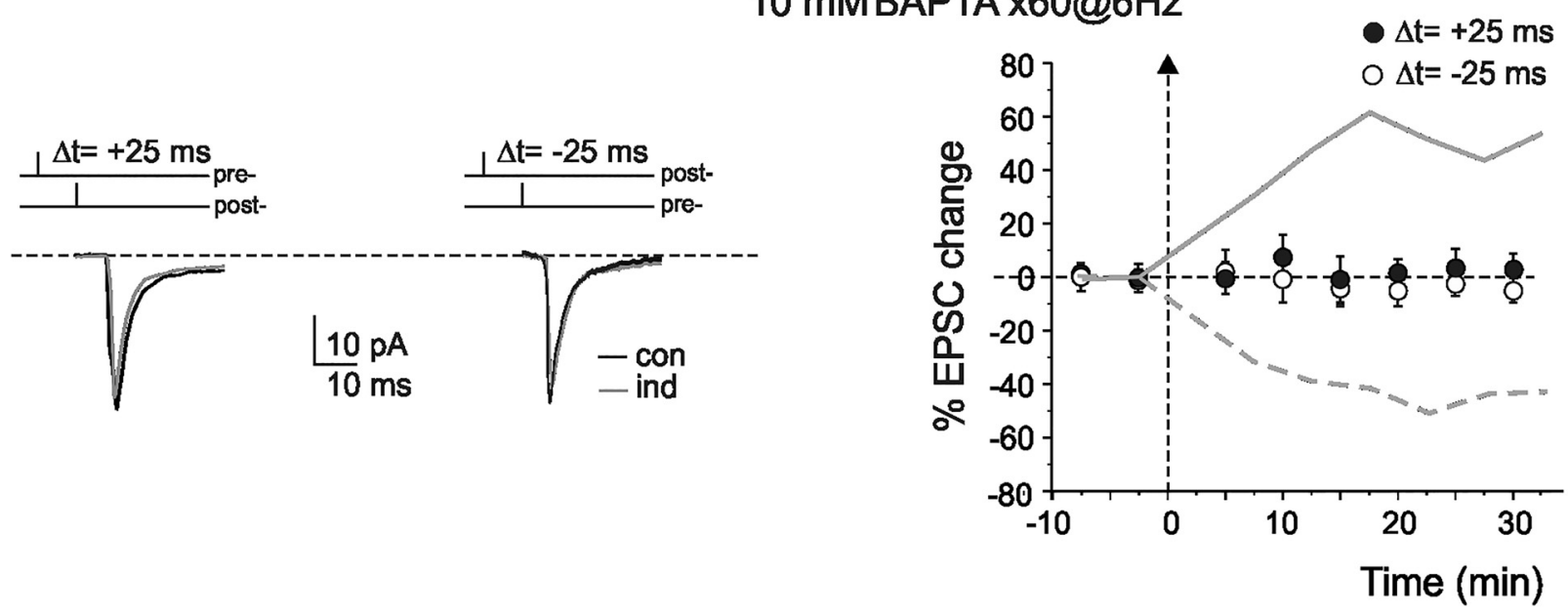

B

NO GABAZINE x60@6Hz

$\Delta \mathrm{t}=+25 \mathrm{~ms}$

O $\Delta \mathrm{t}=-25 \mathrm{~ms}$

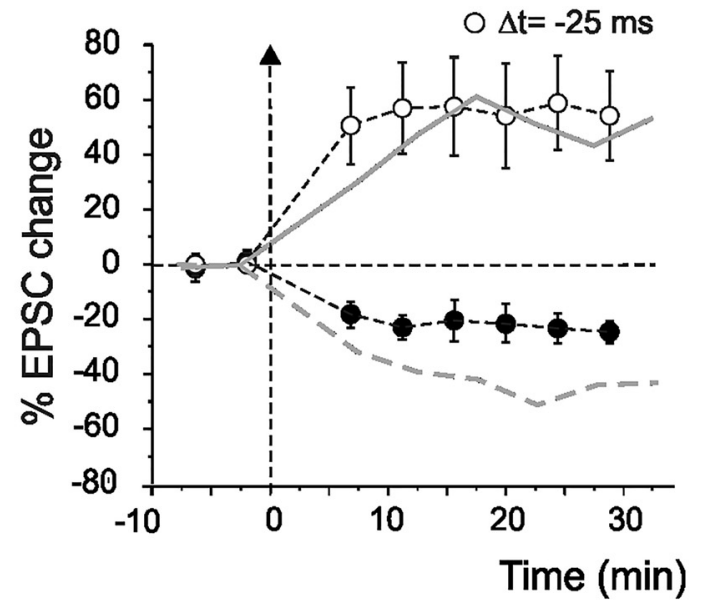

Figure 4. STDP dependence on postsynaptic $\mathrm{Ca}^{2+}$ changes and GABA-A receptors. A, Buffering of postsynaptic $\mathrm{Ca}^{2+}$ with $10 \mathrm{~mm}$ BAPTA blocked the induction of LTP. Left, Sample traces of EPSC in control (con) and $20 \mathrm{~min}$ after STDP induction (ind) in a single cell (average of 100 sweeps) with $10 \mathrm{~mm}$ BAPTA in the intracellular solution. Right, The time course shows average changes in EPSC amplitude after STDP induction using either 0.1 (gray lines) or $10 \mathrm{~mm}$ BAPTA-containing intracellular solution. Dashed line indicates the induction time. Each point indicates the average of 50 contiguous EPSC measurements. Data are mean \pm SEM. B, Postsynaptic GABA receptor-mediated inhibition inverted STDP phase dependence. Left, Sample traces of EPSCs in control (con) and 20 min after STDP induction (ind) in a single cell (average of 100 sweeps) without gabazine. Right, The time course shows average changes in EPSC amplitude after STDP induction using either $10 \mu \mathrm{M}$ (gray lines; replotted from Fig. 1A) or no gabazine-containing extracellular solution. Dashed line indicates the induction time. Each point indicates the average of 50 contiguous EPSC measurements. Data are mean \pm SEM.

dependent induction, like other forms of LTP and LTD at this and other central synapses (Artola and Singer, 1993; D'Angelo et al., 1999; Malenka and Bear, 2004; D’Errico et al., 2009).

STDP has been reported to show complex dependence on inhibitory GABA-A receptors (Sivakumaran et al., 2009). In a set of experiments, the GABA-A receptor antagonist gabazine was omitted from the extracellular solution. Figure $4 B$ shows the time course of EPSC changes. Surprisingly enough, the removal of gabazine inverted STDP, so that st-LTD occurred with positive EPSP/AP phase (at $\Delta t=25 \mathrm{~ms},-27.7 \pm 4.7 \%, n=5 ; p<0.05$ ), whereas st-LTP occurred with negative EPSP/AP phase (at $\Delta t=$ $-25 \mathrm{~ms}, 51.0 \pm 17.5 \%, n=5 ; p<0.01$ ). These results indicate that GABA-A receptor activation can exert a dramatic effect on mossy fiber-granule cell STDP similar to that reported at neocortical synapses (Fino et al., 2010). In the continuation of the work, only experiments in the presence of gabazine have been performed.
The nature of postsynaptic calcium changes during STDP

The relationship between $\left[\mathrm{Ca}^{2+}\right]_{i}$ changes and STDP was investigated by $\mathrm{Ca}^{2+}$ imaging measurements using $200 \mu \mathrm{M}$ OG1 in the patch pipette (Gall et al., 2005; D'Errico et al., 2009). The $\left[\mathrm{Ca}^{2+}\right]_{i}$ increase in the granule cell dendritic endings (Fig. $5 A, B$ ), where the mossy fiber synapses impinge, was significantly higher after st-LTP than st-LTD induction $\left[\left(\Delta \mathrm{F} / \mathrm{F}_{0}\right)_{\max }=0.31 \pm 0.08 v \mathrm{~s}\right.$ $0.19 \pm 0.028, n=4 ; p<0.05]$. It should also be noted that the $\left[\mathrm{Ca}^{2+}\right]_{\mathrm{i}}$ increase started with a greater delay during st-LTD than st-LTD induction ( $5.9 \pm 0.3 \mathrm{~s}$ vs $3.2 \pm 0.2 \mathrm{~s}, n=4 ; p<0.05$; Fig. $5 C$ ). As consequence of combined changes in the size and delay of $\left[\mathrm{Ca}^{2+}\right]_{\mathrm{i}}$ transients, the underlying area (which is related to the total amount of calcium displaced in the cytoplasm) was also significantly increased (Fig. 5C). The relationship between STDP and the maximum $\left[\mathrm{Ca}^{2+}\right]_{i}$ changes is reported in Figure $5 D$, showing that the shift between st-LTD and st-LTP occurs across a $\sim 30 \%\left[\mathrm{Ca}^{2+}\right]_{\mathrm{i}}$ increase. 
A

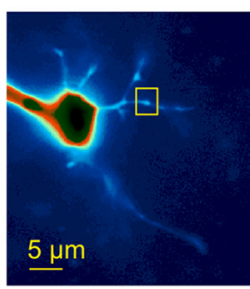

\section{$\mathrm{x} 60 @ 6 \mathrm{~Hz}\left(\Delta \mathrm{F} / \mathrm{F}_{0}\right)$}

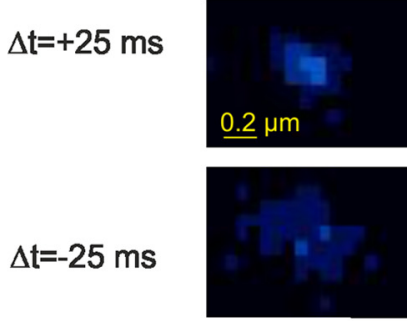

basal
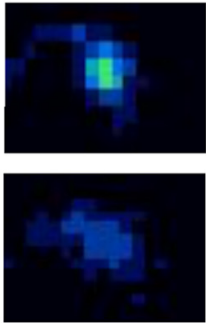

$6.16 \mathrm{~s}$
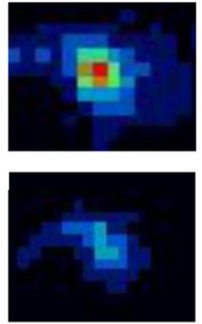

$11.72 \mathrm{~s}$
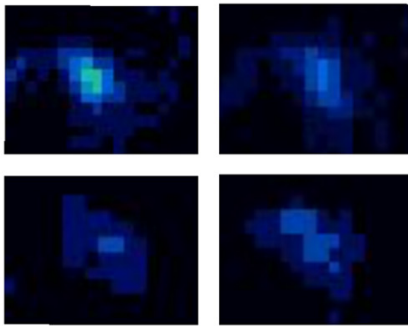

18.27 s

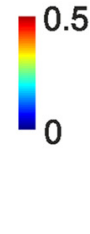

21.82 s

B

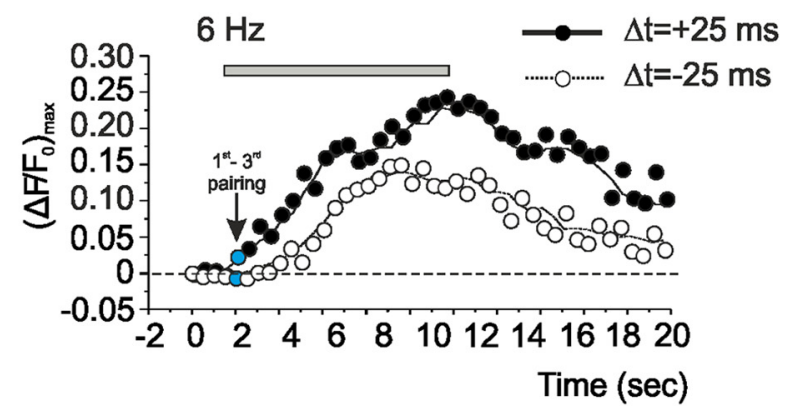

C
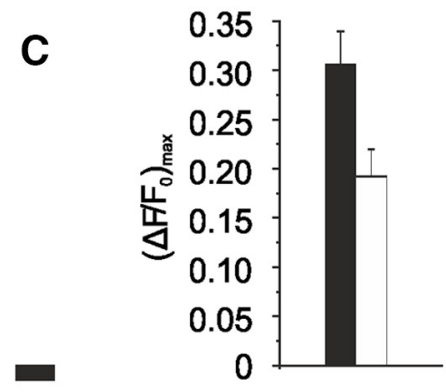

$\Delta \mathrm{t}=+25 \mathrm{~ms}$

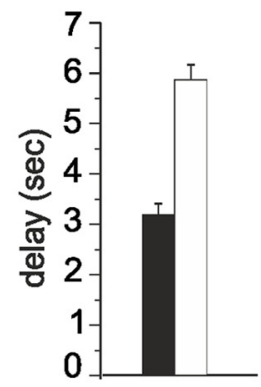

D
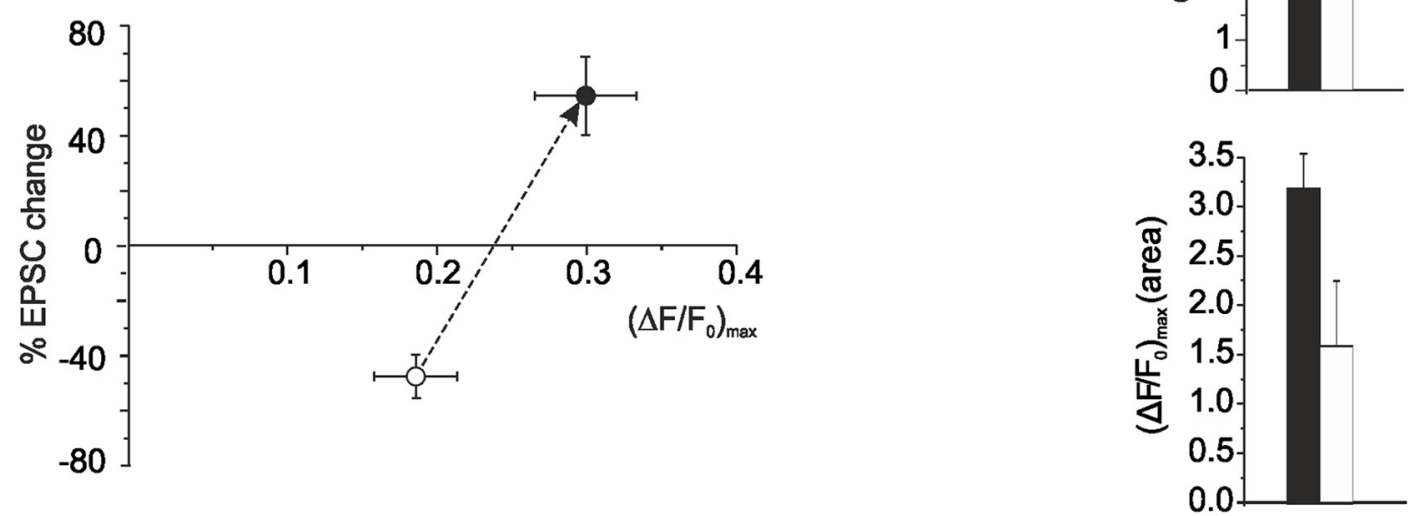

Figure 5. Intradendritic $\mathrm{Ca}^{2+}$ transients evoked during STDP induction protocols. Analysis of $\mathrm{Ca}^{2+}$ transients elicited by the STDP induction protocol at $6 \mathrm{~Hz}$ in granule cells filled with $200 \mu \mathrm{m}$ 0G1.A, Top, Fluorescence image of a GrC filled with $200 \mu \mathrm{M}$ OG1. Scale bar, $5 \mu \mathrm{m}$. Fluorescence intensity is color coded with arbitrary units within an interval chosen to allow the visualization of the synaptic terminals. Bottom, The series of pseudo-ratio images illustrate fluorescence changes $\Delta \mathrm{F} / \mathrm{F}_{0}$ during evoked EPSP paired with spike at $\Delta t= \pm 25 \mathrm{~ms}$. Yellow square represents the ROl used for measurements. Scale bar, $0.2 \mu \mathrm{m}$. $B$, Traces represent the background-subtracted kinetics of fluorescence changes $\left(\Delta \mathrm{F} / \mathrm{F}_{0}\right)_{\text {max }}$ for different STDP induction protocols $(\Delta t= \pm 25 \mathrm{~ms})$. The stimulation starts $2 \mathrm{~s}$ after the beginning of the recording. Gray bar represents the duration of STDP protocols. Each point indicates the $\mathrm{Ca}^{2+}$ transient in response to three consecutive EPSP-AP (or AP-EPSP) pairings. It should be noted that, at the beginning of the pairing period (blue point, i.e., after 3 pairings), the $\mathrm{Ca}^{2+}$ transient was still small and attained plateau near the end of the pairing period (20th point, i.e., after 60 pairings). $C$, Histograms compare the $\left(\Delta \mathrm{F} / \mathrm{F}_{0}\right)_{\max }$ amplitude and area, and delay of $\mathrm{Ca}^{2+}$ transients induced by evoked EPSP paired with spike at $\Delta t= \pm 25 \mathrm{~ms}$. $D$, The relationship between intracellular $\mathrm{Ca}^{2+}$ changes, $\left[\mathrm{Ca}^{2+}\right]_{\mathrm{i}}$, and STDP obtained during evoked EPSP paired with the spike at $\Delta t= \pm 25 \mathrm{~ms}$. 
A

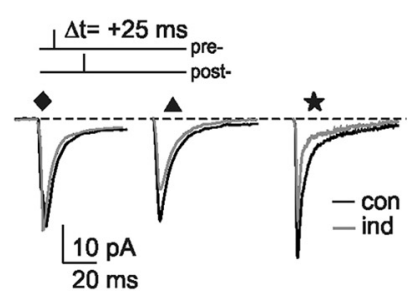

B

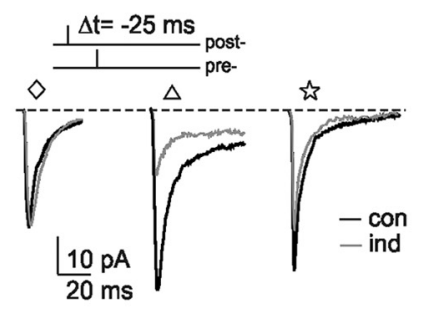

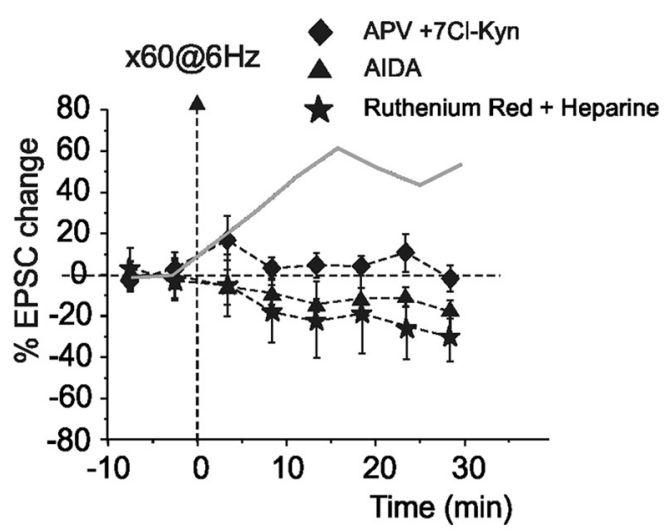

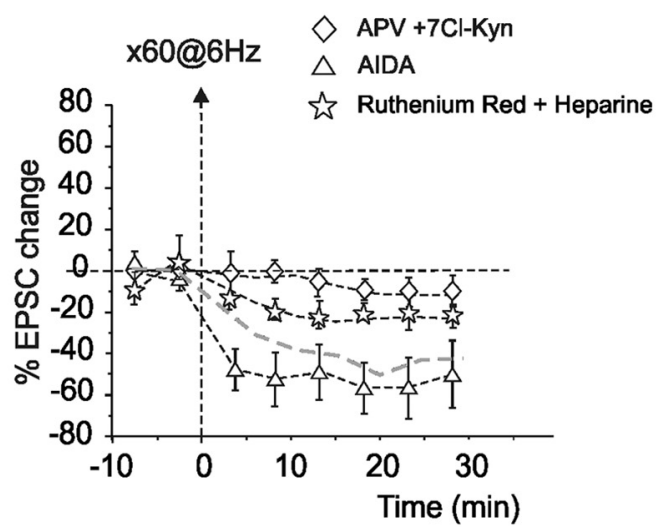

\section{C}

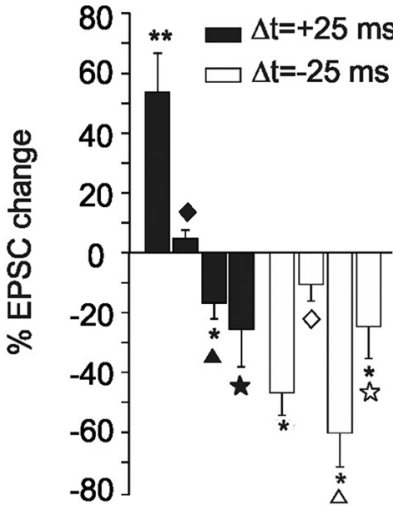

Figure 6. $\mathrm{Ca}^{2+}$ sources for STDP. Effect of blocking NMDA and mGlu receptors and calcium release from internal stores. Application of $50 \mu \mathrm{M} \mathrm{D}-\mathrm{APV}$ and $50 \mu \mathrm{M} 7-\mathrm{Cl}-\mathrm{Kyn}$ acid prevented both LTP and LTD induction ( $\Delta t= \pm 25 \mathrm{~ms}$ ). Application of $15 \mu \mathrm{M}$ AIDA had no effect on LTD induction ( $\Delta t=-25 \mathrm{~ms}$ ) but blocked LTP induction ( $\Delta t=25 \mathrm{~ms})$. Coapplication of $1 \mathrm{mg} / \mathrm{ml}$ heparin and 10 $\mu \mathrm{m}$ ruthenium red in the postsynaptic pipette determined the same effect on STDP induction shown with AIDA perfusion. Dashed line indicates the induction time. $A$, Left, EPSC traces (average of 100 individual sweeps) represent the changes observed following LTP induction in the presence of D-APV, AIDA, and heparin + ruthenium red. Right, Average time course of EPSC amplitude changes in the presence of D-APV, AIDA, and heparin + ruthenium red. Continuous line indicates St-LTP induction in control conditions. B, Left, EPSC traces (average of 100 individual sweeps) represent the changes observed following LTD induction in the presence of D-APV, AIDA, and heparin + ruthenium red. Right, Average time course of EPSC amplitude changes in the presence of D-APV, AIDA, and heparin + ruthenium red. Gray dashed line indicates st-LTD induction in control conditions. C, Average magnitude of st-LTP and st-LTD 20 min after STDP induction in the presence of D-APV, AIDA, and heparin + ruthenium red. Data are mean \pm SEM.

\section{Sensitivity of STDP induction to NMDA and mGlu receptor antagonists}

To examine the induction mechanism underlying STDP (Fig. 6), we first evaluated the involvement of NMDARs, which are primarily responsible for the postsynaptic $\left[\mathrm{Ca}^{2+}\right]_{i}$ changes required for both LTP and LTD at several glutamatergic synapses (D'Angelo et al., 1999; Malenka and Bear, 2004; Dan and Poo, 2006; D'Errico et al., 2009). When the NMDAR blockers D-APV $(50 \mu \mathrm{M})$ and $7-\mathrm{Cl}-\mathrm{Kyn}$ acid $(50 \mu \mathrm{M})$ were added to the extracellular solution, STDP protocols failed to induce either st-LTP $(4.7 \pm 2.9 \%, n=5 ; p=0.2)$ or st-LTD $(-10.6 \pm 5.5 \%, n=6 ; p=$ 0.2 . Because, in several cases, activation of mGluRs is also required for LTD and LTP induction (Egger et al., 1999; Bender et al., 2006; D'Errico et al., 2009), we further examined whether st-LTP and st-LTD induction at mossy fiber-granule cell synapse depended mGluRs. During extracellular application of the mGluR antagonist AIDA $(15 \mu \mathrm{M})$, protocols used for st-LTD induction still caused a significant EPSC reduction $(-60.4 \pm$ $11.3 \%, n=4 ; p<0.05)$ that was not different from that observed without the drug $(p=0.3)$. However, during a similar AIDA application, protocols used for st-LTP induction proved inefficient and a significant st-LTD $(-16.9 \pm 5.4 \%, n=5 ; p<0.05)$ was observed in turn.
These experiments indicated that both st-LTP and st-LTD required activation of NMDARs, but only st-LTP required mGluR activation for induction. Further pharmacological experiments were performed to determine the engagement of intracellular cascades related to inositol 1,4,5-triphosphate ( $\left.\mathrm{IP}_{3}\right)$ receptor- and ryanodine (Ryn) receptor-mediated $\mathrm{Ca}^{2+}$ elevation. We used heparin, a blocker of $\mathrm{IP}_{3} \mathrm{R}$-mediated calcium release from intracellular stores (Ghosh et al., 1988) and ruthenium red, a blocker of Ryn receptors and calcium-induced calcium release from intracellular stores (Khodakhah and Armstrong, 1997). During intracellular coapplication of heparin $(1 \mathrm{mg} / \mathrm{ml})$ and ruthenium red $(10 \mu \mathrm{M})$ through the patch pipette, protocols used for st-LTD induction still caused a significant EPSC reduction $(-24.6 \pm 8.3 \%, n=5 ; p<0.05)$ that not was significantly different from that observed without the blockers $(p=0.1)$. However, during a similar heparin and ruthenium red coapplication, protocols used for st-LTP induction proved inefficient in inducing potentiation $(-25.5 \pm 12.5 \%, n=5 ; p=0.1)$, with an EPSC change that was significantly smaller from that observed without the blockers $(p<0.001)$.

These results are consistent with the notion that NMDA receptors are needed for both st-LTP and st-LTD and that the mGluRs and an intracellular second messenger cascade control- 
A

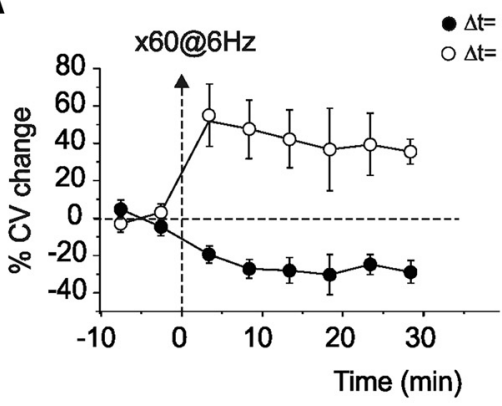

$\Delta \mathrm{t}=+25 \mathrm{~ms}$

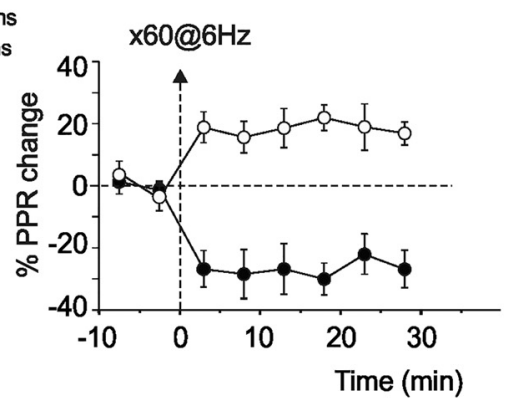

$\Delta \mathrm{t}=+25 \mathrm{~ms}$

B $\square \Delta \mathrm{t}=-25 \mathrm{~ms}$

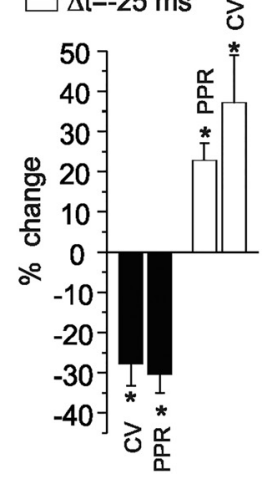

Figure 7. Changes in CV and PPR during STDP expression. $A$, Average time course of CV and PPR after STDP induction. Dashed line indicates the induction time. Each point is the average of 50 contiguous EPSC measurements. Data are mean \pm SEM. B, Histogram compares CV and PPR changes following STDP induction ( $\Delta t= \pm 25 \mathrm{~ms}$ ).

ling calcium release from internal stores are needed for st-LTP only.

\section{Mechanisms of STDP expression: PPR and CV}

The mechanism of STDP expression was first assessed by analyzing the PPR (interstimulus interval $20 \mathrm{~ms}$ ) and the coefficient of variation of EPSCs (CV) (Fig. 7A). PPR is generally considered to reflect changes in the probability of transmitter release in a pair of stimuli (Zucker and Regehr, 2002), whereas CV is a readout of presynaptic variability of quantal transmitter release upon repeated stimulation normalized by the mean (Malinow and Tsien, 1990; Manabe et al., 1993). Therefore, a presynaptic expression mechanism should be accompanied by reduced PPR and CV for st-LTP and by increased PPR and CV for st-LTD. During st-LTP, PPR changed from $0.94 \pm 0.05$ to $0.76 \pm 0.05(n=5)$, showing therefore a significantly reduction by $18.2 \pm 6.5 \%(p<0.05, n=$ 5 ), whereas during st-LTD PPR changed from $0.68 \pm 0.10 \%$ to $0.84 \pm 0.08(n=4)$, showing a significantly increase by $26.3 \pm$ 9.4\% $(p<0.01, n=4)$. During st-LTP, CV changed from $0.33 \pm$ 0.04 to $0.24 \pm 0.04(n=9)$, showing a significantly reduction by $-27.9 \pm 5.4 \%(p<0.005, n=9)$, whereas during st-LTD CV changed from $0.27 \pm 0.03$ to $0.37 \pm 0.05(n=9)$, showing a significant increase by $37.1 \pm 11.9 \%(p<0.05, n=9)$. The PPR and $\mathrm{CV}$ changes followed the time course of EPSC amplitude (Fig. $1 A, B$ ), suggesting that the a bidirectional modification in quantum content took part to mossy fiber-granule cell STDP.

\section{Mechanisms of STDP expression: minis amplitude and frequency}

There is no single method to ascertain the nature of quantal release. For example, the validity of PPR and CV analysis alone has been questioned (mostly at single vesicular release synapses) because changes in quantal content may reflect either increased/ decreased transmitter release or expression of new postsynaptic clusters, or possibly, in theory, a simultaneous increase/decrease in quantal size (Nicoll and Malenka, 1999). It is therefore useful to combine PPR and CV analysis with other measurements of neurotransmission phenomena. Additional evidence for a presynaptic or postsynaptic mechanism of expression for STDP can be obtained by analyzing mEPSCs before and after induction of STDP (Kullmann and Nicoll, 1992; Wyllie et al., 1994; Malgaroli et al., 1995), a method that is especially useful at multiquantal release synapses like the present one (Sola et al., 2004; Saviane and Silver, 2006). Because mEPSCs accounted for the whole spontaneous mossy fiber activity, in STDP experiments mEPSCs were recorded without TTX and were used to characterize the STDP expression mechanism (Sola et al., 2004). Here, to prevent mEPSC changes from being obscured by the contribution of nonpotentiated synapses, we activated as many synapses as possible. Indeed, in the recordings used for minis analysis, the EPSCs measured $-73.4 \pm 8.9 \mathrm{pA}(n=9)$, indicating activation of three to four mossy fibers by comparison with single fiber EPSCs measured in similar recording conditions (Sola et al., 2004).

After EPSP-AP pairing with $\Delta t=25 \mathrm{~ms}$, the EPSCs showed $22.0 \pm 6.3 \%$ increase $(p<0.05, n=5)$ attesting effective st-LTP induction. Interestingly, in the same recordings the mEPSCs showed significant increase in both amplitude $(16.9 \pm 6.3 \%, n=$ 5 ; $p<0.05$; Fig. $8 A, D)$ and frequency $(18.1 \pm 8.7 \%, n=5 ; p<$ $0.05)$. After AP-EPSP pairing with $\Delta t=-25 \mathrm{~ms}$, the EPSCs showed $-43.8 \pm 4.0 \%$ change $(p<0.05, n=4)$ attesting effective st-LTD induction. In this case, the mEPSCs showed a decrease in both amplitude $(-20.1 \pm 8.8 \%, n=4 ; p<0.05)$ and frequency $(-29.8 \pm 11.1 \%, n=4 ; p<0.05$; Fig. $8 A, D)$. Further evidence about STDP mechanisms was given by analyzing mEPSC amplitude distributions (Fig. 8B). Accordingly, we measured the mode of the distributions, reflecting the most frequent mEPSC amplitude, and the maximum mEPSC size. After EPSP-AP pairing with $\Delta t=25 \mathrm{~ms}$, the histogram mode showed a significant shift toward larger amplitudes $(4.9 \pm 1.2 \mathrm{pA}$ shift, $n=$ $5 ; p<0.05)$ and the mEPSC maximum amplitude significantly increased ( $8.6 \pm 1.3 \mathrm{pA}$ shift, $n=5 ; p<0.005)$. Conversely, after EPSP-AP pairing with $\Delta t=-25 \mathrm{~ms}$, the histogram mode showed a significant shift toward smaller amplitudes $(-3.5 \pm 1.1 \mathrm{pA}$ shift, $n=4 ; p<0.05)$ and the mEPSC maximum amplitude significantly decreased $(-8.0 \pm 1.3 \mathrm{pA}$ shift, $n=4 ; p<0.01)$. The variations in mEPSC amplitude were accompanied by a substantial shift in the cumulative frequency distributions (Fig. 8C). Together, these results suggested that a modification in quantum size took part to mossy fiber-granule cell STDP.

\section{Extended analysis of STDP expression mechanisms over the whole $\Delta t$ range}

The analysis of STDP expression was extended over the whole $\Delta t$ range covered in these experiments. The EPSC mean amplitude changes were accompanied by symmetric CV variations, so that $\mathrm{CV}$ changes were usually positive for st-LTD and negative for st-LTP. In Figure 9A, the ensemble CV-M plot for LTP and LTD showed a significant negative linear correlation passing near the origin $\left(R^{2}=-0.637 ; n=53 ; p<0.0001\right)$. Therefore, STDP 


\section{A}

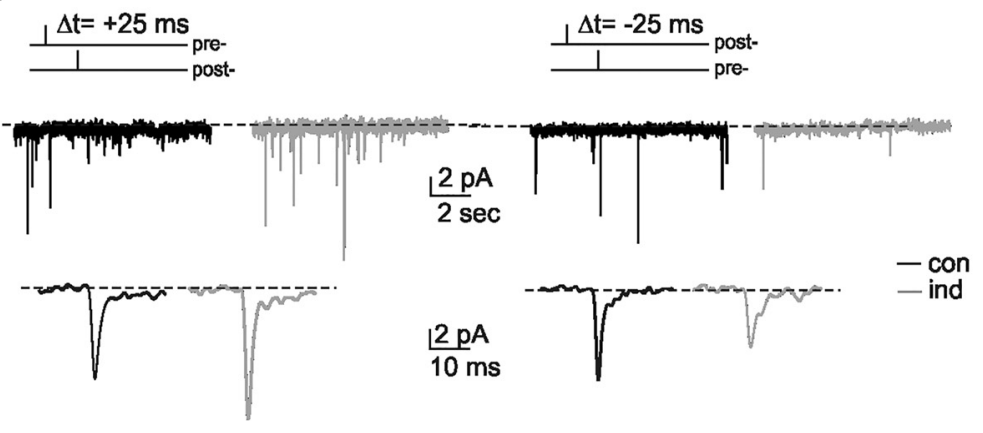

B

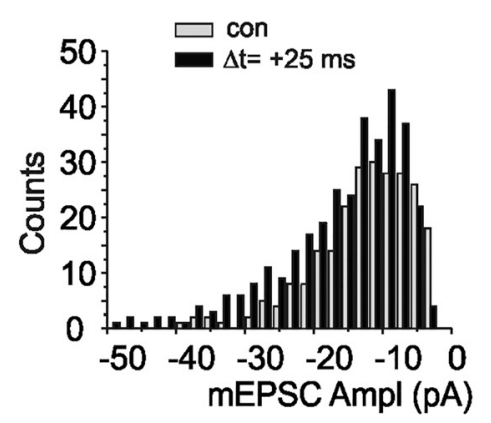

C

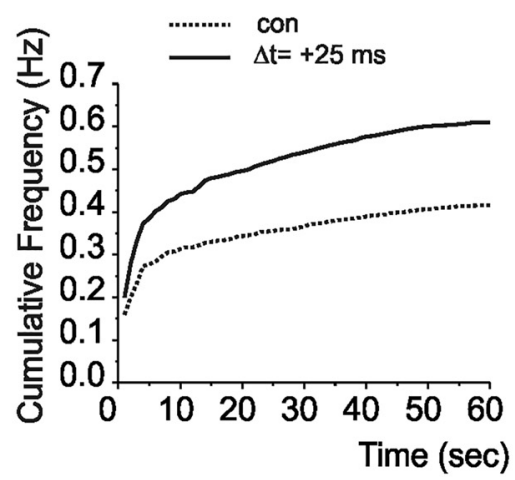

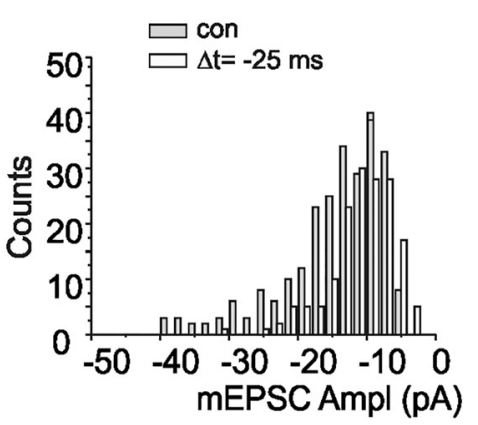

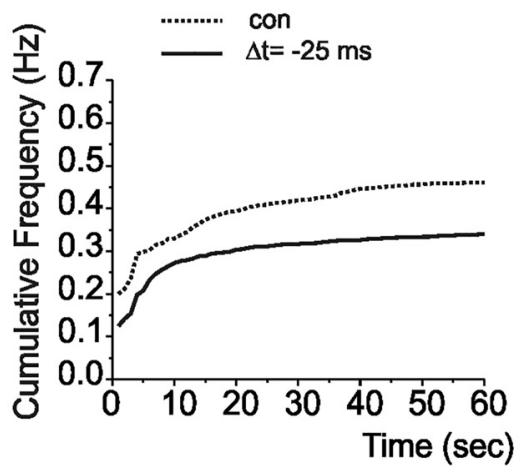

D

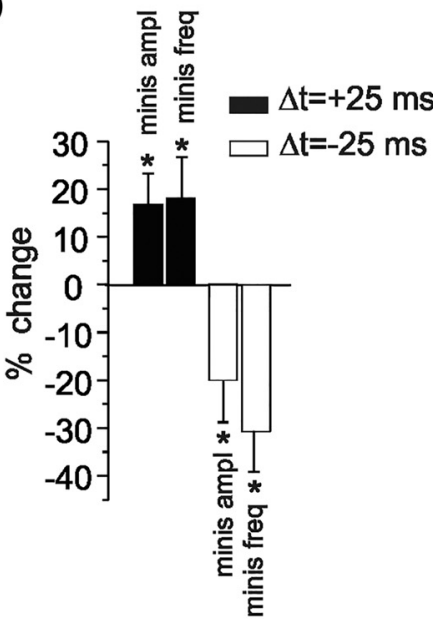

Figure 8. $m E P S C$ recordings during STDP. Consecutive tracings showing spontaneous activity before and after STDP induction ( $\Delta t= \pm 25 \mathrm{~ms}$ ). Following st-LTP induction, both mEPSC amplitude and frequency increased; whereas following st-LTD induction, both mEPSC amplitude and frequency decreased. $A$, Representative examples of mEPSC before and after STDP induction ( $\Delta t= \pm 25 \mathrm{~ms}$ ). $\boldsymbol{B}$, mEPSC amplitude distributions before (gray) and during STDP (blue or yellow). mEPSC amplitude histograms were constructed with $2 \mathrm{pA}$ per bin. Note the shift of the histogram mode with a change in maximum mEPSC amplitude. $\boldsymbol{C}$, Cumulative frequency distributions before (dashed line) and after STDP induction (continuous line; $\Delta t= \pm 25$ ms). $\boldsymbol{D}$, The histogram compares $\mathrm{mEPSC}$ amplitude and frequency following STDP induction $(\Delta \mathrm{T}= \pm 25 \mathrm{~ms})$.

changes appeared to exploit a continuous modulation of expression mechanisms with a neutral point $\sim 0$-phase.

A further way to determine whether EPSC changes depend on quantum content or quantum size is to plot $\left(\mathrm{CV}_{\text {post }} / \mathrm{CV}_{\text {pre }}\right)^{-2}$ versus $\left(\mathrm{M}_{\text {post }} / \mathrm{M}_{\text {pre }}\right)$ (Bekkers and Stevens, 1990; Malinow and Tsien, 1990; Sola et al., 2004) (see Materials and Methods; Fig. $9 B$ ). Using binomial statistics (Eq. 3), this plot has the property that the unitary slope diagonal divides points determined by increased quantum content (on or above the diagonal) from those determined by increased quantum size (below the diagonal). In our experiments, st-LTP points fell both above the diagonal corresponding to a rise in quantum content and below the diagonal corresponding to an increase of quantum size. The st-LTD points corresponding to a reduction in quantum content or in quantum size fell in the complementary sectors. Together, these results point to a mixed presynaptic and postsynaptic STDP expression mechanism (Sola et al., 2004; D'Errico et al., 2009).

\section{Discussion}

This work reveals the existence of STDP at the rat cerebellar mossy fiber-granule cell synapse. While st-LTP was induced when EPSP led AP, st-LTD was induced when AP led EPSP according to the Hebbian principle of coincidence detection between presynaptic and postsynaptic activity. In this respect, mossy fiber-granule cell STDP is similar to that observed at different synapses mostly located in the neocortex and hippocampus (Magee and Johnston, 1997; Markram et al., 1997; Bi and Poo, 1998; Debanne et al., 1998; Egger et al., 1999; Feldman, 2000; Sjöström et al., 2001; Froemke and Dan, 2002; Dan and Poo, 2004; Tzounopoulos et al., 2004). To our knowledge, this is the 
A

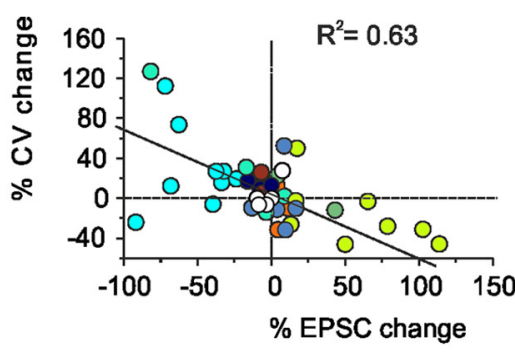

B

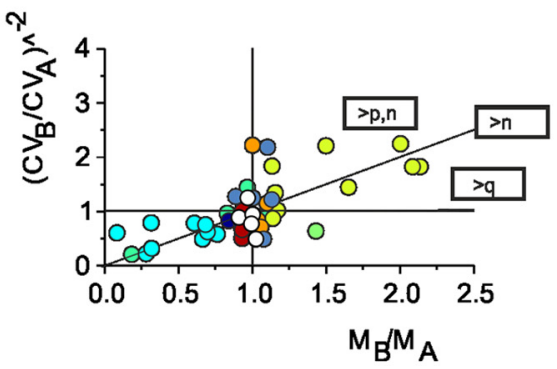

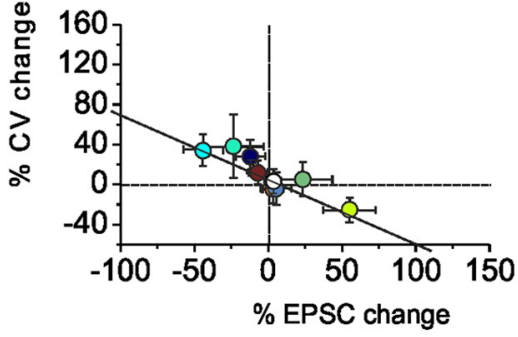

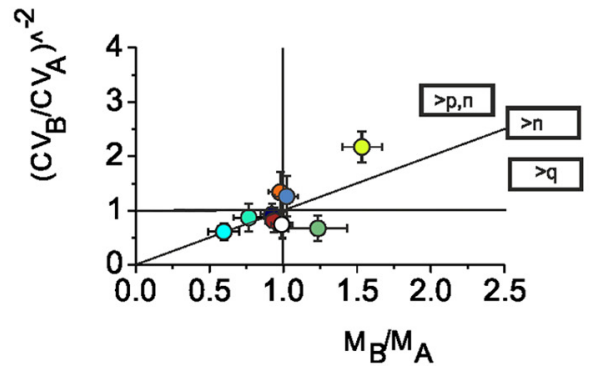

$0 \mid \mathrm{ISI}=+100 \mathrm{~ms}$
$0 \mathrm{ISI}=+50 \mathrm{~ms}$
$0 \mathrm{ISI}=+25 \mathrm{~ms}$
$0 \mathrm{ISI}=+5 \mathrm{~ms}$
$0 \mathrm{ISI}=-5 \mathrm{~ms}$
$0 \mathrm{ISI}=-25 \mathrm{~ms}$
$0 \mathrm{ISI}=-50 \mathrm{~ms}$
ISI=-100 ms
0 ISI=random

O ISI=random

Figure 9. The relationship between CV and mean EPSC amplitude during STDP expression. Plots represent obtained points at different $\Delta t$ (same as in Fig. 1). Single data points (left) and average data grouped per category (right). $A$, Plots represent the relationship between CV and EPSC changes at different $\Delta t$. During st-LTP ( $\Delta t=25 \mathrm{~ms})$, EPSC CV decreased and EPSC amplitude increased, whereas the opposite occurred during st- $\mathrm{LTD}(\Delta t=-25 \mathrm{~ms})$. Linear regression over the points was statistically significant ( lope $=-0.54 \pm 0.11$, intercept $=11.6 \pm 5.2 ; R^{2}=-0.63 . ; n=$ $45 ; p<0.0001) \cdot B,\left(\mathrm{CV}_{\mathrm{B}} / \mathrm{CV}_{\mathrm{A}}\right)^{-2}<=>\left(\mathrm{M}_{\mathrm{B}} / \mathrm{M}_{\mathrm{A}}\right)$ shows that most points fall close to the unitary diagonal. Data in average plots are mean $\pm \mathrm{SEM}$.

first evidence that Hebbian STDP occurs in the cerebellum because previous observations only reported either non-Hebbian STDP at the parallel fiber-Purkinje-like cell synapse (Safo and Regehr, 2008; Piochon et al., 2012) or anti-Hebbian STDP at the corresponding synapses of cerebellum-like structures (Bell et al., 1997; Tzounopoulos et al., 2004; Wu et al., 2015). It should be noted that, different from Purkinje cells, granule cells show a rapid and complete spike back-propagation into the dendrites (Diwakar et al., 2009; Dover et al., 2016), so that information about AP generation can be faithfully transmitted to synaptic sites providing a key requirement for Hebbian STDP.

Mossy fiber-granule cell STDP was detected using repeated cycles on the theta-frequency band and depended on precise positive or negative phase locking, such that it was abolished by random pairing. It should be noted that STDP was no longer visible at $1 \mathrm{~Hz}$ and that, with an STDP time-window covering 50 ms, STDP should not extend beyond $20 \mathrm{~Hz}$ (i.e., the "aliasing" frequency at which the positive and negative phase coincide). In a tentative reconstruction (Fig. 3C), STDP was comprised within the $1-20 \mathrm{~Hz}$ region and appeared as a bifurcation around the BCM (Bienenstock et al., 1982) curve generated by 0-phase locking at the same synapse (D'Errico et al., 2009).

\section{STDP induction involves a combination of membrane and cytoplasmic mechanisms}

At the mossy fiber-granule cell synapse, the induction of STDP required a postsynaptic intracellular $\mathrm{Ca}^{2+}$ increase that was significantly larger for st-LTP than st-LTD. Although both st-LTP and st-LTD depended on NMDAR activation, only st-LTP was prevented by mGluR antagonists and by blockers of RynR and $\mathrm{IP}_{3} \mathrm{R}$. Thus, STDP seems to use molecular pathways in common with burst duration/frequency modulated LTP and LTD.

It is generally accepted that the pattern of postsynaptic $\mathrm{Ca}^{2+}$ increase plays a critical role in determining the polarity of longterm synaptic plasticity, such that a moderate $\mathrm{Ca}^{2+}$ increase in- duces LTD, an intermediate $\mathrm{Ca}^{2+}$ increase has poor effect and high $\mathrm{Ca}^{2+}$ increase induces LTP (Malenka and Bear, 2004). In STDP, the $\mathrm{Ca}^{2+}$ increase determined by NMDAR activation can act as a trigger for both st-LTP and st-LTD induction (Bi and Poo, 1998; Shouval et al., 2002; Bi and Rubin, 2005; Froemke et al., 2005; Dan and Poo, 2006) as well as for other forms of plasticity (e.g., see Malenka and Bear, 2004). Our results suggest that a similar STDP induction mechanism applies also to the mossy fiber-granule cell synapse of cerebellum. Accordingly, the higher $\mathrm{Ca}^{2+}$ increase observed at positive EPSP/AP phase probably reflects the enhanced unblock of NMDA channels when a simultaneous AP raises membrane depolarization. However, the switch between st-LTD and st-LTP also requires additional mechanisms based on mGluRs and intracellular release of calcium from RynRand $\mathrm{IP}_{3} \mathrm{R}$-gated internal stores.

The narrow coincidence detection window for st-LTD $(\Delta t=$ $-25 \mathrm{~ms}$ ) is consistent with known NMDAR (Ascher et al., 1992; D'Angelo et al., 1994) and AP kinetics (D’Angelo et al., 1998). With a precession of up to $30-40 \mathrm{~ms}$, AP afterhyperpolarization can depress subsequent EPSP-related membrane depolarization and therefore NMDAR unblock (Froemke et al., 2005). This would lead to a reduced $\mathrm{Ca}^{2+}$ influx, which in turn activates phosphatases, such as calcineurin (Wang et al., 2005), rather than kinases, downregulating NMDARs and promoting synaptic depression (Seol et al., 2005; Pawlak and Kerr, 2008). Conversely, an AP in phase with the EPSP could temporarily enhance $\mathrm{Ca}^{2+}$ influx reversing the chain of effects and leading to activate kinases as well as a $\mathrm{Ca}^{2+}$-induced $\mathrm{Ca}^{2+}$ release from intracellular stores (Berridge, 1998; Finch and Augustine, 1998; Sabatini et al., 2001), eventually causing st-LTP. Indeed, calcium stores blockade using heparin and ruthenium red prevented st-LTP but not st-LTD, suggesting that this pathway provided an additional source of postsynaptic $\mathrm{Ca}^{2+}$ needed for potentiation.

The mGluRs activated during repeated stimulation cycles may serve to reinforce the intracellular $\mathrm{Ca}^{2+}$ signal as a consequence 
of perisynaptic glutamate buildup (Irving et al., 1992; Kinney and Slater, 1993). At the concentrations used, AIDA is especially effective on mGluR1, the dominant mGluR expressed postsynaptically in cerebellar granule cells (Fotuhi et al., 1993). Thus, because mGluR1 activates PLC to generate $\mathrm{IP}_{3}$, which triggers calcium release from intracellular stores, AIDA may eventually prevent the activation of this reinforcing pathway.

On the same line, the STDP inversion determined by GABA-A receptors may involve a regulation of membrane potential and intracellular calcium (Fino et al., 2010). In summary, although the precise mechanisms require further clarification, NMDA, mGlu, and GABA-A receptors, membrane ionic channels, and calcium stores contribute to tune intracellular calcium changes and the phase-dependent switch between st-LTD and st-LTP.

\section{STDP expression involves a combination of presynaptic and postsynaptic mechanisms}

It was of interest to compare the STDP expression mechanisms with those of LTP and LTD induced by duration/frequency modulated trains. CV and PPR significantly and persistently increased with st-LTD and decreased with st-LTP. In support to their specificity, the magnitude and time course of these changes paralleled that in EPSC amplitude. Because PPR and CV changes with a sign opposite to EPSC amplitude changes are assumed to reflect changes in quantal release (Schulz et al., 1994; Saviane and Silver, 2006), the present results suggest that presynaptic mechanisms are involved in STDP expression. If the expression mechanism was purely presynaptic, though, a pure mEPSC frequency increase should be expected. However, mEPSC revealed significant bidirectional changes both in amplitude and frequency. Thus, a change in quantum size should have occurred together with that in quantum content and contribute to explain STDP expression. Consistent with a composite presynaptic and postsynaptic mechanism, the st-LTP and st-LTP points fell in sectors of the $\left(\mathrm{CV}_{\mathrm{B}} /\right.$ $\left.\mathrm{CV}_{\mathrm{A}}\right)^{-2}$ versus $\left(\mathrm{M}_{\mathrm{B}} / \mathrm{M}_{\mathrm{A}}\right)$ plot corresponding to changes in both quantum size and quantum content (Bekkers and Stevens, 1990; Malinow and Tsien, 1990; Sola et al., 2004).

This composite mechanism differs from that reported using similar recording and analysis methods in the same preparation when LTP and LTD are induced by bursts of variable duration or trains of variable frequency (Sola et al., 2004; D'Errico et al., 2009). In burst/train-dependent plasticity, the magnitude of LTP and LTD was significantly smaller than st-LTP and st-LTD. Moreover, in LTP and LTD, expression turned out to be purely presynaptic and the estimated changes in release probability were in fair agreement with the EPSC amplitude changes. It is tempting to speculate that the larger changes observed in st-LTP and st-LTD compared with burst/train-dependent plasticity are caused by the additional engagement of postsynaptic mechanisms (e.g., see Isaac et al., 1996) using a classical pairing protocol.

\section{Conclusions and functional implications}

The observation of STDP at the mossy fiber-granule cell synapse opens new perspectives to understand how plasticity might operate at the cerebellum input stage. STDP was optimal in the theta-frequency band $(6-10 \mathrm{~Hz})$. This is actually a range of frequencies at which coherent oscillations have been detected in the granular layer (Pellerin and Lamarre, 1997; Hartmann and Bower, 1998). Thus, STDP at mossy fiber-granule cell synapse could provide a mean to coordinate learning at the cerebellar input stage with activity generated in extracerebellar structures, such as the neocortex and striatum, which show coherent oscil- lations with the cerebellum (Courtemanche and Lamarre, 2005; Courtemanche et al., 2013; Frederick et al., 2014). Accordingly, a recent theoretical work predicted that the granular layer circuit conforms to a learning scheme, such that incoming patterns are first stored in an oscillating inhibitory interneuron network (Kleberg et al., 2014; Garrido et al., 2016), like that formed by GABAergic Golgi cells (Dugué et al., 2009), to later instruct STDP at the mossy fiber-granule cells synapse. It is interesting in this context that activation of GABA-A receptors could actually invert the STDP phase dependence, making it anti-Hebbian. Although the molecular mechanisms of GABAergic regulation remain puzzling (Sivakumaran et al., 2009; Fino et al., 2010), it could provide a powerful mechanism multiplying the number of possible STDP configurations at mossy fiber-granule cell synapses. STDP could therefore be instrumental to bind cerebellar learning to lowfrequency oscillations in the thalamocortical and hippocampal circuits to coordinate learning and memory during specific functional states, such as voluntary movement, resting attentiveness, and sleep (Parker, 2015; Cheron et al., 2016). Specific experiments may now be designed to investigate the implications of mossy fiber-granule cell STDP for cerebellar learning and for STDP-based control schemes (Luque et al., 2016).

\section{References}

Abbott LF, Nelson SB (2000) Synaptic plasticity: taming the beast. Nat Neurosci 3 [Suppl]:1178-1183.

Armano S, Rossi P, Taglietti V, D’Angelo E (2000) Long-term potentiation of intrinsic excitability at the mossy fiber-granule cell synapse of rat cerebellum. J Neurosci 20:5208-5216. Medline

Artola A, Singer W (1993) Long-term depression of excitatory synaptic transmission and its relationship to long-term potentiation. Trends Neurosci 16:480-487. CrossRef Medline

Ascher P, Dieudonné S, Macdonald J, Sather W (1992) Kinetics of activation, deactivation and desensitization of the "NMDA" glutamate receptor. C R Acad Sci III 314:75-77. Medline

Bekkers JM, Stevens CF (1990) Presynaptic mechanism for long-term potentiation in the hippocampus. Nature 346:724-729. CrossRef Medline

Bell CC, Han VZ, Sugawara Y, Grant K (1997) Synaptic plasticity in a cerebellum-like structure depends on temporal order. Nature 387:278281. CrossRef Medline

Bender VA, Bender KJ, Brasier DJ, Feldman DE (2006) Two coincidence detectors for spike timing-dependent plasticity in somatosensory cortex. J Neurosci 26:4166-4177. CrossRef Medline

Berridge MJ (1998) Neuronal calcium signaling. Neuron 21:13-26. CrossRef Medline

Bi GQ, Poo MM (1998) Synaptic modifications in cultured hippocampal neurons: dependence on spike timing, synaptic strength, and postsynaptic cell type. J Neurosci 18:10464-10472. Medline

Bi GQ, Rubin J (2005) Timing in synaptic plasticity: from detection to integration. Trends Neurosci 28:222-228. CrossRef Medline

Bienenstock EL, Cooper LN, Munro PW (1982) Theory for the development of neuron selectivity: orientation specificity and binocular interaction in visual cortex. J Neurosci 2:32-48. Medline

Caporale N, Dan Y (2008) Spike timing-dependent plasticity: a Hebbian learning rule. Annu Rev Neurosci 31:25-46. CrossRef Medline

Cassenaer S, Laurent G (2007) Hebbian STDP in mushroom bodies facilitates the synchronous flow of olfactory information in locusts. Nature 448:709-713. CrossRef Medline

Cathala L, Holderith NB, Nusser Z, DiGregorio DA, Cull-Candy SG (2005) Changes in synaptic structure underlie the developmental speeding of AMPA receptor-mediated EPSCs. Nat Neurosci 8:1310-1318. CrossRef Medline

Celikel T, Szostak VA, Feldman DE (2004) Modulation of spike timing by sensory deprivation during induction of cortical map plasticity. Nat Neurosci 7:534-541. CrossRef Medline

Cheron G, Márquez-Ruiz J, Dan B (2016) Oscillations, timing, plasticity, and learning in the cerebellum. Cerebellum 15:122-138. CrossRef Medline

Courtemanche R, Lamarre Y (2005) Local field potential oscillations in pri- 
mate cerebellar cortex: synchronization with cerebral cortex during active and passive expectancy. J Neurophysiol 93:2039-2052. CrossRef Medline

Courtemanche R, Robinson JC, Aponte DI (2013) Linking oscillations in cerebellar circuits. Front Neural Circuits 7:125. CrossRef Medline

Dan Y, Poo MM (2004) Spike timing-dependent plasticity of neural circuits. Neuron 44:23-30. CrossRef Medline

Dan Y, Poo MM (2006) Spike timing-dependent plasticity: from synapse to perception. Physiol Rev 86:1033-1048. CrossRef Medline

D'Angelo E (2014) The organization of plasticity in the cerebellar cortex: from synapses to control. Prog Brain Res 210:31-58. CrossRef Medline

D'Angelo E, De Zeeuw CI (2009) Timing and plasticity in the cerebellum: focus on the granular layer. Trends Neurosci 32:30-40. CrossRef Medline

D’Angelo E, Rossi P, Taglietti V (1994) Voltage-dependent kinetics of $\mathrm{N}$-methyl-D-aspartate synaptic currents in rat cerebellar granule cells. Eur J Neurosci 6:640-645. CrossRef Medline

D’Angelo E, De Filippi G, Rossi P, Taglietti V (1995) Synaptic excitation of individual rat cerebellar granule cells in situ: evidence for the role of NMDA receptors. J Physiol 484:397-413. CrossRef Medline

D’Angelo E, De Filippi G, Rossi P, Taglietti V (1998) Ionic mechanism of electroresponsiveness in cerebellar granule cells implicates the action of a persistent sodium current. J Neurophysiol 80:493-503. Medline

D’Angelo E, Rossi P, Armano S, Taglietti V (1999) Evidence for NMDA and mGlu receptor-dependent long-term potentiation of mossy fiber-granule cell transmission in rat cerebellum. J Neurophysiol 81:277-287. Medline

D'Angelo E, Koekkoek SK, Lombardo P, Solinas S, Ros E, Garrido J, Schonewille M, De Zeeuw CI (2009) Timing in the cerebellum: oscillations and resonance in the granular layer. Neuroscience 162:805-815. CrossRef Medline

Debanne D, Gähwiler BH, Thompson SM (1998) Long-term synaptic plasticity between pairs of individual CA3 pyramidal cells in rat hippocampal slice cultures. J Physiol 507:237-247. CrossRef Medline

D’Errico A, Prestori F, D’Angelo E (2009) Differential induction of bidirectional long-term changes in neurotransmitter release by frequency-coded patterns at the cerebellar input. J Physiol 587:5843-5857. CrossRef Medline

Diwakar S, Magistretti J, Goldfarb M, Naldi G, D’Angelo E (2009) Axonal $\mathrm{Na}^{+}$channels ensure fast spike activation and back-propagation in cerebellar granule cells. J Neurophysiol 101:519-532. CrossRef Medline

Dover K, Marra C, Solinas S, Popovic M, Subramaniyam S, Zecevic D, D'Angelo E, Goldfarb M (2016) FHF-independent conduction of action potentials along the leak-resistant cerebellar granule cell axon. Nat Commun 7:12895. CrossRef Medline

Dugué GP, Brunel N, Hakim V, Schwartz E, Chat M, Lévesque M, Courtemanche R, Léna C, Dieudonné S (2009) Electrical coupling mediates tunable low-frequency oscillations and resonance in the cerebellar Golgi cell network. Neuron 61:126-139. CrossRef Medline

Eccles JC (1967) Circuits in the cerebellar control of movement. Proc Natl Acad Sci U S A 58:336-343. CrossRef Medline

Egger V, Feldmeyer D, Sakmann B (1999) Coincidence detection and changes of synaptic efficacy in spiny stellate neurons in rat barrel cortex. Nat Neurosci 2:1098-1105. CrossRef Medline

Feldman DE (2000) Timing-based LTP and LTD at vertical inputs to layer II/III pyramidal cells in rat barrel cortex. Neuron 27:45-56. CrossRef Medline

Finch EA, Augustine GJ (1998) Local calcium signalling by inositol-1,4,5trisphosphate in Purkinje cell dendrites. Nature 396:753-756. CrossRef Medline

Fino E, Paille V, Cui Y, Morera-Herreras T, Deniau JM, Venance L (2010) Distinct coincidence detectors govern the corticostriatal spike timingdependent plasticity. J Physiol 588:3045-3062. CrossRef Medline

Fotuhi M, Sharp AH, Glatt CE, Hwang PM, von Krosigk M, Snyder SH, Dawson TM (1993) Differential localization of phosphoinositide-linked metabotropic glutamate receptor (mGluR1) and the inositol 1,4,5trisphosphate receptor in rat brain. J Neurosci 13:2001-2012. Medline

Frederick A, Bourget-Murray J, Chapman CA, Amir S, Courtemanche R (2014) Diurnal influences on electrophysiological oscillations and coupling in the dorsal striatum and cerebellar cortex of the anesthetized rat. Front Syst Neurosci 8:145. CrossRef Medline

Froemke RC, Dan Y (2002) Spike-timing-dependent synaptic modification induced by natural spike trains. Nature 416:433-438. CrossRef Medline

Froemke RC, Poo MM, Dan Y (2005) Spike-timing-dependent synaptic plasticity depends on dendritic location. Nature 434:221-225. CrossRef Medline

Fung TK, Law CS, Leung LS (2016) Associative spike-timing dependent potentiation of the basal dendritic excitatory synapses in the hippocampus in vivo. J Neurophysiol 115:3264-3274. CrossRef Medline

Gall D, Prestori F, Sola E, D’Errico A, Roussel C, Forti L, Rossi P, D’Angelo E (2005) Intracellular calcium regulation by burst discharge determines bidirectional long-term synaptic plasticity at the cerebellum input stage. J Neurosci 25:4813-4822. CrossRef Medline

Gao Z, van Beugen BJ, De Zeeuw CI (2012) Distributed synergistic plasticity and cerebellar learning. Nat Rev Neurosci 13:619-635. CrossRef Medline

Garrido JA, Luque NR, Tolu S, D’Angelo E (2016) Oscillation-driven spiketiming dependent plasticity allows multiple overlapping pattern recognition in inhibitory interneuron networks. Int J Neural Syst 26:1650020. CrossRef Medline

Ghosh TK, Eis PS, Mullaney JM, Ebert CL, Gill DL (1988) Competitive, reversible, and potent antagonism of inositol 1,4,5-trisphosphateactivated calcium release by heparin. J Biol Chem 263:11075-11079. Medline

Hartmann MJ, Bower JM (1998) Oscillatory activity in the cerebellar hemispheres of unrestrained rats. J Neurophysiol 80:1598-1604. Medline

Hebb DO (1949) The organization of behavior. New York: Wiley.

Irving AJ, Collingridge GL, Schofield JG (1992) Interactions between $\mathrm{Ca}^{2+}$ mobilizing mechanisms in cultured rat cerebellar granule cells. J Physiol 456:667-680. CrossRef Medline

Isaac JT, Oliet SH, Hjelmstad GO, Nicoll RA, Malenka RC (1996) Expression mechanisms of long-term potentiation in the hippocampus. J Physiol Paris 90:299-303. CrossRef Medline

Kanichay RT, Silver RA (2008) Synaptic and cellular properties of the feedforward inhibitory circuit within the input layer of the cerebellar cortex. J Neurosci 28:8955-8967. CrossRef Medline

Khodakhah K, Armstrong CM (1997) Inositol trisphosphate and ryanodine receptors share a common functional $\mathrm{Ca}^{2+}$ pool in cerebellar Purkinje neurons. Biophys J 73:3349-3357. CrossRef Medline

Kinney GA, Slater NT (1993) Potentiation of NMDA receptor-mediated transmission in turtle cerebellar granule cells by activation of metabotropic glutamate receptors. J Neurophysiol 69:585-594. Medline

Kleberg FI, Fukai T, Gilson M (2014) Excitatory and inhibitory STDP jointly tune feedforward neural circuits to selectively propagate correlated spiking activity. Front Comput Neurosci 8:53. CrossRef Medline

Kullmann DM, Nicoll RA (1992) Long-term potentiation is associated with increases in quantal content and quantal amplitude. Nature 357:240-244. CrossRef Medline

Luque NR, Garrido JA, Naveros F, Carrillo RR, D’Angelo E, Ros E (2016) Distributed cerebellar motor learning: a spike-timing-dependent plasticity model. Front Comput Neurosci 10:17. CrossRef Medline

Magee JC, Johnston D (1997) A synaptically controlled, associative signal for Hebbian plasticity in hippocampal neurons. Science 275:209-213. CrossRef Medline

Malenka RC, Bear MF (2004) LTP and LTD: an embarrassment of riches. Neuron 44:5-21. CrossRef Medline

Malgaroli A, Ting AE, Wendland B, Bergamaschi A, Villa A, Tsien RW, Scheller RH (1995) Presynaptic component of long-term potentiation visualized at individual hippocampal synapses. Science 268:1624-1628. CrossRef Medline

Malinow R, Tsien RW (1990) Presynaptic enhancement shown by wholecell recordings of long-term potentiation in hippocampal slices. Nature 346:177-180. CrossRef Medline

Manabe T, Wyllie DJ, Perkel DJ, Nicoll RA (1993) Modulation of synaptic transmission and long-term potentiation: effects on paired pulse facilitation and EPSC variance in the CA1 region of the hippocampus. J Neurophysiol 70:1451-1459. Medline

Mapelli L, Rossi P, Nieus T, D’Angelo E (2009) Tonic activation of GABAB receptors reduces release probability at inhibitory connections in the cerebellar glomerulus. J Neurophysiol 101:3089-3099. CrossRef Medline

Markram H, Lübke J, Frotscher M, Sakmann B (1997) Regulation of synaptic efficacy by coincidence of postsynaptic APs and EPSPs. Science 275: 213-215. CrossRef Medline

Markram H, Gerstner W, Sjöström PJ (2011) A history of spike-timingdependent plasticity. Front Synaptic Neurosci 3:4. CrossRef Medline

Marr D (1969) A theory of cerebellar cortex. J Physiol 202:437-470. CrossRef Medline 
Nicoll RA, Malenka RC (1999) Expression mechanisms underlying NMDA receptor-dependent long-term potentiation. Ann N Y Acad Sci 868:515525. CrossRef Medline

Nielsen TA, DiGregorio DA, Silver RA (2004) Modulation of glutamate mobility reveals the mechanism underlying slow-rising AMPAR EPSCs and the diffusion coefficient in the synaptic cleft. Neuron 42:757-771. CrossRef Medline

Nieus T, Sola E, Mapelli J, Saftenku E, Rossi P, D’Angelo E (2006) LTP regulates burst initiation and frequency at mossy fiber-granule cell synapses of rat cerebellum: experimental observations and theoretical predictions. J Neurophysiol 95:686-699. CrossRef Medline

Osborne LC, Hohl SS, Bialek W, Lisberger SG (2007) Time course of precision in smooth-pursuit eye movements of monkeys. J Neurosci 27:29872998. CrossRef Medline

Parker KL (2015) Timing tasks synchronize cerebellar and frontal ramping activity and theta oscillations: implications for cerebellar stimulation in diseases of impaired cognition. Front Psychiatry 6:190. CrossRef Medline

Pawlak V, Kerr JN (2008) Dopamine receptor activation is required for corticostriatal spike-timing-dependent plasticity. J Neurosci 28:2435-2446. CrossRef Medline

Pellerin JP, Lamarre Y (1997) Local field potential oscillations in primate cerebellar cortex during voluntary movement. J Neurophysiol 78:3502_3507. Medline

Piochon C, Kruskal P, Maclean J, Hansel C (2012) Non-Hebbian spiketiming-dependent plasticity in cerebellar circuits. Front Neural Circuits 6:124. CrossRef Medline

Sabatini BL, Maravall M, Svoboda K (2001) $\mathrm{Ca}(2+)$ signaling in dendritic spines. Curr Opin Neurobiol 11:349-356. CrossRef Medline

Safo P, Regehr WG (2008) Timing dependence of the induction of cerebellar LTD. Neuropharmacology 54:213-218. CrossRef Medline

Saviane C, Silver RA (2006) Errors in the estimation of the variance: implications for multiple-probability fluctuation analysis. J Neurosci Methods 153:250-260. CrossRef Medline

Schulz PE, Cook EP, Johnston D (1994) Changes in paired-pulse facilitation suggest presynaptic involvement in long-term potentiation. J Neurosci 14:5325-5337. Medline

Seol GH, Kim MY, Liang GH, Kim JA, Kim YJ, Oh S, Suh SH (2005) Sphingosine-1-phosphate-induced intracellular $\mathrm{Ca}^{2+}$ mobilization in human endothelial cells. Endothelium 12:263-269. CrossRef Medline

Shouval HZ, Bear MF, Cooper LN (2002) A unified model of NMDA receptor-dependent bidirectional synaptic plasticity. Proc Natl Acad Sci U S A 99:10831-10836. CrossRef Medline

Silver RA, Traynelis SF, Cull-Candy SG (1992) Rapid-time-course miniature and evoked excitatory currents at cerebellar synapses in situ. Nature 355:163-166. CrossRef Medline
Silver RA, Cull-Candy SG, Takahashi T (1996) Non-NMDA glutamate receptor occupancy and open probability at a rat cerebellar synapse with single and multiple release sites. J Physiol 494:231-250. CrossRef Medline

Sivakumaran S, Mohajerani MH, Cherubini E (2009) At immature mossy fiber-CA3 synapses, correlated presynaptic and postsynaptic activity persistently enhances GABA release and network excitability via BDNF and cAMP-dependent PKA. J Neurosci 29:2637-2647. CrossRef Medline

Sjöström PJ, Häusser M (2006) A cooperative switch determines the sign of synaptic plasticity in distal dendrites of neocortical pyramidal neurons. Neuron 51:227-238. CrossRef Medline

Sjöström PJ, Turrigiano GG, Nelson SB (2001) Rate, timing, and cooperativity jointly determine cortical synaptic plasticity. Neuron 32:11491164. CrossRef Medline

Sola E, Prestori F, Rossi P, Taglietti V, D’Angelo E (2004) Increased neurotransmitter release during long-term potentiation at mossy fibregranule cell synapses in rat cerebellum. J Physiol 557:843-861. CrossRef Medline

Stuart GJ, Häusser M (2001) Dendritic coincidence detection of EPSPs and action potentials. Nat Neurosci 4:63-71. CrossRef Medline

Timmann D, Watts S, Hore J (1999) Failure of cerebellar patients to time finger opening precisely causes ball high-low inaccuracy in overarm throws. J Neurophysiol 82:103-114. Medline

Tzounopoulos T, Kim Y, Oertel D, Trussell LO (2004) Cell-specific, spike timing-dependent plasticities in the dorsal cochlear nucleus. Nat Neurosci 7:719-725. CrossRef Medline

von Kitzing E, Jonas P, Sakmann B (1994) Quantal analysis of excitatory postsynaptic currents at the hippocampal mossy fiber-CA3 pyramidal cell synapse. Adv Second Messenger Phosphoprotein Res 29:235-260. CrossRef Medline

Wang HX, Gerkin RC, Nauen DW, Bi GQ (2005) Coactivation and timingdependent integration of synaptic potentiation and depression. Nat Neurosci 8:187-193. CrossRef Medline

Wu C, Martel DT, Shore SE (2015) Transcutaneous induction of stimulustiming-dependent plasticity in dorsal cochlear nucleus. Front Syst Neurosci 9:116. CrossRef Medline

Wyllie DJ, Manabe T, Nicoll RA (1994) A rise in postsynaptic $\mathrm{Ca}^{2+}$ potentiates miniature excitatory postsynaptic currents and AMPA responses in hippocampal neurons. Neuron 12:127-138. CrossRef Medline

Zhang LI, Tao HW, Holt CE, Harris WA, Poo M (1998) A critical window for cooperation and competition among developing retinotectal synapses. Nature 395:37-44. CrossRef Medline

Zucker RS, Regehr WG (2002) Short-term synaptic plasticity. Annu Rev Physiol 64:355-405. CrossRef Medline 